\title{
Transplanting Anglo-American accounting oversight boards to a diverse institutional context
}

\author{
Constantinos Caramanis \\ Department of Business Administration \\ Athens University of Economics and Business \\ 76 Patision Street \\ 104-34 Athens, Greece \\ Tel: + $30210620-3367$ \\ E-mail: c.caramanis@aueb.gr \\ Emmanouil Dedoulis \\ Department of Business Administration \\ Athens University of Economics and Business \\ 76 Patision Street \\ 104-34 Athens, Greece \\ Tel: + 30210 820-3453 \\ E-mail: ededoulis@aueb.gr \\ Stergios Leventis \\ International Hellenic University \\ School of Economics and Business Administration \\ $14^{\text {th }} \mathrm{klm}$ Thessaloniki-Moudania \\ 57101 Thessaloniki, Greece \\ Tel: + 302310 807-541 \\ E-mail: s.leventis@ihu.edu.gr \\ and \\ Aston Business School, UK
}

Keywords

Accounting regulation, auditing, independent oversight, institutions, globalization, politics

\section{Acknowledgments}

The authors are grateful to David Cooper, the editor of Accounting, Organizations and Society, and two anonymous reviewers for their valuable comments and suggestions. Previous versions of this manuscript have benefited from comments received from S. Walker, participants at the 33rd Annual Congress of the EAA (Istanbul, Turkey), and colleagues at the Athens University of Economics and Business. Finally, the authors express their gratitude to senior politicians, state officials, civil servants, regulators, and practicing auditors for being available for interviews and for providing invaluable primary research data.

This research was funded by the Research Centre of the Athens University of Economics and Business. 


\title{
Transplanting Anglo-American accounting oversight boards to a diverse institutional context
}

\begin{abstract}
The introduction of accounting and auditing oversight boards (OBs) has been promoted on a global scale as a key component of the international financial architecture that has emerged over the past two decades. Such institutions, modeled on the Anglo-American tradition, are domestically organized and embedded within distinctively diverse institutional contexts. Their role is to ease agency problems, improve the quality of financial reporting, and help provide stability in the global financial system. We employ an institutional approach, located within the broader political economy framework of global capitalism, to examine the establishment and operation of the new regulatory regime in Greece. Greece, a member of the European Union, exhibits characteristics of a "delegative" democracy, i.e. a traditionally weak institutionalization, reform (in)capacity problems and a clientelistic political system. Our case study shows that the formation and operation of the newly-established system of oversight is conditioned by local political and economic constraints and, thus, does not automatically translate into concrete benefits for the quality of financial reporting. We also draw attention to the structural mismatch between a progressing globalized financial integration and the fragmented nature of the system of oversight, and illustrate that OBs' independence from local governments is an important but neglected issue.
\end{abstract}

Keywords

Accounting regulation, auditing, independent oversight, institutions, globalization, politics 


\section{Introduction}

Internationally, the history of corporate accounting and auditing is replete with failures and scandals, followed by waves of regulation (e.g. Malsch \& Gendron, 2011; Zeff, 2003). In the past two decades of advancing globalization, reforms in the accounting domain have taken place within what Wade (2007a) calls the Standards-Surveillance-Compliance (SSC) doctrine, a regulatory framework of globally-integrated financial markets that aims to provide stability in the marketplace (Büthe \& Mattli, 2011; Davies \& Green, 2008; Wade, 2007a, 2007b). This new dogma entails the use of comprehensive and universal standards, as well as codes of good practice, whose application would be overseen and enforced by a gamut of regulatory institutions and agencies - official or unofficial, national or global (Cooper \& Robson, 2006; Humphrey, Loft, \& Woods, 2009).

A key element of the emerging international financial reporting infrastructure is the introduction of systems of oversight for accounting and audit practice, independent of the profession, which appears to signal an end to the tradition of self-regulation. Accounting and auditing oversight boards (OBs) serve as a basic mechanism for tackling perennial problems in corporate financial reporting and auditing, within the broader complex and hierarchical global regulatory system (Arnold, 2012; Humphrey et al., 2009; Wade, 2007a). OBs emerged in the US under the SarbanesOxley Act (US Congress, 2002), in the EU under the (new) Eighth Directive (European Commission, 2006), and in other countries (Malsch \& Gendron, 2011). Their establishment rests on the assumption that they can operate efficiently and effectively to ease agency problems, improve the quality of financial reporting, and help to restore the trust of investors and the public (European Commission, 2001a, 2006, 2010; US Congress, 2002, 2010).

The system of oversight for accounting and auditing is domestically organized and embedded within distinctively diverse local political, economic, legal, and cultural contexts (e.g. Kaufmann, Kraay \& Mastruzzi, 2013). O’Donnell (1994) argues that, for historical and socio-political reasons, some countries consistently exhibit a marked weakness in introducing social and economic reforms and in building strong and functional institutions of horizontal accountability. These countries, termed by O'Donnell as "delegative" democracies, are characterized by a highly clientelistic political system and state ineffectiveness, standing in contrast to other countries that have shown a history of successful reforms and strong institutionalization. Thus, the effectiveness of the operation 
of OBs at a domestic level warrants in-depth empirical evaluation (Arnold, 2012; Malsch \& Gendron, 2011), given their importance for the stability of the global financial system (Wade, 2007a, 2007b) and the variability of local institutional backdrops (Dyson \& Goetz, 2003; O’Donnell, 1994).

In this article, we adopt an institutional approach located within the broader political economy framework of global capitalism (Arnold, 2009b, 2012; Wade, 2007a, 2007b; see also Chapman, Cooper \& Miller, 2009) to examine the creation and operation of an OB in a local European setting. We focus on O'Donnell's (1994) conceptualization of delegative democracy and supplement our framework with literature on Europeanization, which indicates that reform (in)capacity problems and weak institutionalization occur even within the EU and the euro area (Dyson \& Goetz, 2003; Featherstone \& Papadimitriou, 2008). We place emphasis on the interaction between global structural elements, institutions, influences and pressures (namely, the unfolding of the SSC project), and on local socio-political characteristics that may condition the establishment and effective operation of OBs at the local (state) level. Our focus is Greece, which offers a clear vantage point for examining the issue at hand for two main reasons. First, the country is known for its clientelistic political system and well-documented reform (in)capacity problems (e.g. Featherstone \& Papadimitriou, 2008). Second, Greece has been in a deep, multifaceted crisis since 2008 (OECD, 2011a, 2011b), illustrating the importance of each nation to the stability of the new, complex, and interdependent international financial system (International Monetary Fund, 2013).

With a wealth of empirical material (written evidence and interview data), our national case study illustrates the difficulties and limitations in transplanting Anglo-American (Arnold, 2012) reforms to a diverse socio-political local context. Our study shows that the political practices of clientelism and party patronage, as well as bureaucratic control by the government and a widespread mentality of inertia within the broader state apparatus, have affected ELTE ${ }^{1}$, the Greek OB, since its inception in 2003. As a result, ELTE has remained essentially dormant. In this study, we show that ELTE has failed to become a significant player in Greek accounting and audit practices and demonstrate that improvements are urgently needed in the quality of Greek financial reporting and auditing

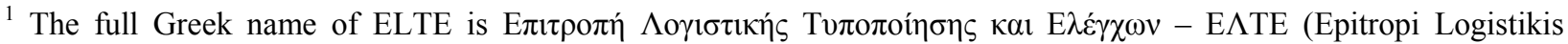
Typopoisis kai Elegchon - ELTE), which translates as the Accounting and Auditing Committee).
} 
(Caramanis \& Papadakis, 2008; Christensen Hail, \& Leuz, 2013; Leuz, Nanda \& Wysocki, 2003; Osma \& Pope, 2011).

This article extends prior work on the establishment of the Greek OB (Blavoukos, Caramanis \& Dedoulis, 2013) and contributes to emerging international academic literature on accounting and auditing oversight (e.g. Malsch \& Gendron, 2011) on several fronts. First, our paper employs O'Donnell's theoretical conception of delegative democracies within a broader political economy framework to create the theoretical backdrop for investigating how local socio-political constraints condition the establishment and operation of an imported institution - a subject that is currently high on the global agenda. In particular, we show that the Greek OB has been stymied since inception by pre-existing local structures and remains essentially a dormant institution, providing no concrete benefits to financial reporting quality. Second, whereas the current system of oversight puts emphasis on ensuring the independence of OBs from the auditing profession, we illustrate that independence from government is an equally important but essentially neglected issue. Specifically, we argue that, while existing arrangements may have saved the oversight system from the Scylla of professional control, they have sailed too close to the Charybdis of state meddling.

Thus, our study draws attention to the structural mismatch between a progressing integration of the interdependent global financial system and the fragmented organization of accounting and auditing oversight on a domestic (national) level. This mismatch raises the question of the effectiveness of local OBs, given the diversity of the domestic socio-political contexts within which they emerge and the rather elementary level of current international or regional (e.g. EU) coordination (Davies \& Green, 2008, pp. 89-91; Humphrey et al., 2009).

Our study is of relevance to several other countries that exhibit, albeit to varying degrees, a tradition of party patronage, clientelism, institutional weaknesses and state ineffectiveness. The findings have implications for various actors and stakeholders in financial reporting. For example, global regulators should realize that independence from the profession, while simultaneously ignoring local institutional impediments, by no means guarantees the operation of effective national OBs across the globe. Furthermore, in the absence of effective oversight, particularly amid a severe financial crisis, there is a real risk that the quality of auditing will fall and audit fees will plunge, conditions that may bring about a major legitimation crisis for the profession. 
The rest of the article is structured as follows: in the next section, we discuss the emergence of accounting and auditing OBs since the early 2000s as a means for regulating globalized capitalism, with particular emphasis on institutional aspects, and we present the research methods employed. We then outline the international and local institutional settings to demonstrate the environment from which the Greek OB emerged. Next, we present the debate in the Greek Parliament to illuminate prevailing perceptions of independence and clientelism, and to sketch the context in which the new $\mathrm{OB}$ was eventually submitted to government control. We then demonstrate the inertia of ELTE through an evaluation of its performance since inception (2003-2013). Concluding remarks and implications appear in the last section.

\section{The political economy of OB establishment: an institutional approach}

As accounting scholars have observed, the internationalization of accounting and auditing practices is not a recent phenomenon (e.g. Hopwood, 2000; Power, 2009). Rather, long historical processes have been at work for centuries, as a result of the expansion of a universalistic commercial culture. Power (2009, p. 331) in particular highlights the need to understand "the history and institutional shape of a changing structural coupling between world-level accounting elements and the preoccupation of state agencies" and calls for a shift of emphasis from the nation-state to the "world system of accounting”. Arnold (2009a, 2009b, 2012) recognizes Power's (2009) position as a useful starting point and argues for an institutional perspective, informed by the political economy of the contemporary inter-state system, to examine the role of accounting in the global economic system. Such a perspective draws attention to the key role of (historically changing) hegemonic states (still the US at the current historical juncture), conflicting interests, and power relations in the governance of global capitalism.

At the turn of the $21^{\text {st }}$ century, a new international financial architecture was under development to provide urgently-needed stability to a global financial system characterized by recurring crises, the rise of finance capital and inequality among states regarding the power to influence the shaping of emerging regulatory apparatuses (Arnold, 2009a, 2009b, 2012; Humphrey et al., 2009; Wade, 2007a, 2007b). This new architecture was sponsored by the G7 (G20 since the crisis of the late 2000s; see Humphrey et al., 2009, p. 812) and other significant actors in international financial systems. It provided for an upgraded role of various international organizations (e.g. International 
Monetary Fund) and the application of a series of global standards and codes of good practice in the management of the global financial system (Wade, 2007a, 2007b). These standards of good practice (the SSC system) cover macroeconomic policy and data transparency, institutional and market infrastructures (including international accounting as well as auditing standards), and financial regulation and supervision (Arnold, 2012, p. 367). The key idea was that adherence to these standards of practice and increased transparency would improve the quality of financial reporting and access to finance, thus further inducing (in a virtuous circle) the observance of these standards (Humphrey et al., 2009).

However, Wade (2007a, 2007b) argues that this new financial architecture promotes the interests of Anglo-American style capitalism and reflects the increasing importance of the finance industry in global economic activity. Furthermore, Arnold (2012) contends that reformers have shown eagerness in rapidly promoting the reforms, regardless of the ability of countries to effectively introduce and assimilate them. Other options, such as slowing down the pace of reforms to give states some breathing space (Arnold, 2012) or setting up truly international regulators to match the global nature of the financial integration (Eatwell \& Taylor, 2000), were rejected at the time.

OBs within the SSC system

A key component of the new regime has been accounting and auditing OBs, which are meant to operate at the state level and to occupy a pivotal role in restoring confidence in financial reporting. OBs, modeled on the Anglo-American tradition, are promoted as a uniform solution to the need for material improvements in the effectiveness of global financial market regulation (Arnold, 2012; Büthe \& Mattli, 2011; Davis \& Green, 2008).

OBs, local or transnational, are complex, multifaceted units of analysis, with important and diverse characteristics. They are established as formal political institutions, operating at the interface between the world of economy and the world of politics (e.g. Büthe \& Mattli, 2011; Davies \& Green, 2008). As actors within the political arena, OBs are part of the wider decision-making system, assumed to produce and/or effect mandatory rules within a given territory (not necessarily confined to the borders of a particular jurisdiction/state) and for a particular domain (e.g. accounting). 
The establishment of accounting and auditing OBs within the SSC context is considered a means to secure an adequate level of quality in financial reporting to facilitate the operation of globalized financial markets (Humphrey et al., 2009; Wade, 2007a, 2007b). In this sense, the establishment of OBs in the 2000s can be understood as a manifestation of the "accounting internationalization" process, which has a long history (Hopwood, 2000; Power, 2009). However, as Power (2009) notes, accounting scholars have long voiced caution or skepticism about the feasibility of eradicating local "constraints" to the internationalization of accounting practice and regulation, as these constraints are culturally and institutionally embedded and exhibit remarkable resilience (e.g. Bromwich \& Hopwood, 1983; Hopwood, 2000, 2009; Puxty et al., 1987).

Other scholars have challenged the suitability of externally-induced change, modeled on the AngloAmerican tradition, because it disregards local factors crucial for the project's success (Arnold, 2012; Wade, 2007a, 2007b). In particular, scholars have questioned the feasibility of pursuing the stability of a global, complex and interdependent financial system through the operation of domestic OBs across the globe. At the same time, local needs for reform are ignored, leaving the imbalances and inequalities among states in the global economic system neglected.

Wade (2007b) suggests that the effectiveness of the system of global oversight should not be taken for granted, and he captures the need for a thorough investigation of OBs in practice thus:

At first glance, transparency, standards and surveillance are as desirable as motherhood and apple pie. To go beyond the first glance we have to ask whether national regulatory authorities have complied with the standards, and whether their compliance makes a difference to the behavior of private market participants (p. 80).

To examine OBs at the local level more closely, we turn to the literature on politico-economic reforms and institution building. O'Donnell (1994) recognizes strong institutions, such as OBs, as key factors for the smooth functioning of the political and economic process and he maintains that the effectiveness of such institutions is contingent on the wider socio-political context (see also Acemoglu \& Robinson, 2012; Schmitter, 1974; Streeck \& Schmitter, 1985). More specifically, O'Donnell (1994) suggests that, for various reasons, including long-term historical factors and the intensity of their socio-economic problems, some countries have failed to develop a state of consolidated, institutionalized democracy, or what he terms "representative democracy". These countries, dubbed "delegative democracies", in contrast to their representative counterparts, tend to have weak institutions (e.g. OBs), often due to intentional strategy. Such countries tend to lack or 
have weak horizontal accountability mechanisms (i.e. a nexus of relatively autonomous institutions that operate as a system of checks and balances to the flow of power). In delegative democracies, institutions that make horizontal accountability operational in practice are often considered "unnecessary encumbrances ... and strenuous efforts [are made] to hamper the development of such institutions" (ibid., pp. 61-62).

Furthermore, the enforcement of a clear distinction between the public and the private interests of office-holders in delegative democracies is cursory, if not absent. In other words, in these countries, whoever wins the elections is in a sense "entitled to govern as he or she sees fit, constrained only by the hard facts of existing power relations and by a constitutionally limited term of office" (ibid., p. 59). In addition, delegative democracies are typically omnipotent in introducing spectacular policy reform packages and in setting up various institutions that often imitate successful examples from advanced countries but are in fact highly impotent, or maybe indifferent, in effectively implementing those decisions in practice (ibid.). In short, delegative democracies tend to exhibit characteristics such as: low-quality public administration with limited independence from political pressure; low commitment to sound policy formulation and implementation; limited confidence in and abidance of the rules; weaknesses in contract enforcement, and regulatory capture by elites and private interests (O’Donnell, 1994; see also Kaufmann et al., 2013).

One qualification is warranted with regard to O'Donnell's (1994) ideal typology of democracies. Representative and delegative democracies should not be considered polar opposites; rather, they differ only in the degree, albeit often significant, to which they exhibit their particular characteristics, and it is not always easy to make a sharp distinction between them.

Building strong institutions and effectively introducing material reforms in member states is critical for the EU, given the political objectives of economic and political integration (European Commission, 2001b). Yet the difficulties involved show remarkable resilience (e.g. Balkir, Bolukbasi \& Ertugal, 2013; Falkner \& Treib, 2008; Falkner, Treib, Hartlapp \& Leiber, 2005). EU reform initiatives are, in practice, imposed on states exhibiting distinctively diverse social, political and institutional backgrounds (e.g. Dyson \& Goetz, 2003). Dyson and Goetz (2003) maintain that the peripheral, or less central, states in southern Europe (e.g. Portugal, Italy, Greece, Spain) exert considerably less influence than core countries on the formulation of EU policy. As they 
convincingly argue, the Europeanization project is highly likely to be a mere "top-down" process for peripheral southern member states and may produce variable and contingent outcomes due to social, political and economic differences among various member states.

Studies have shown that the implementation of EU-inspired reforms by member states is often associated with significant gaps between the intended purposes and the actual effects of the Europeanization project (Featherstone \& Papadimitriou, 2008; Radaelli, 2003). In a sense, when change is imposed from above (Mouzelis, 1995), the complex, multifaceted and interdependent domestic system of economic and political power illustrates a form of social "homeostasis" (Simon, 1962, p. 467). Reforms are internalized in such a way that the system essentially maintains its ex ante equilibrium. Material change is minimized, delayed, postponed and even averted (Mouzelis, 1995; Pagoulatos, 2003). Blavoukos et al. (2013) examine aspects of the function of the Greek OB within the context of the Europeanization process - which, inter alia, involves the curtailment of a member state's policy-making role and the disempowerment of domestic technocracy. The authors use Radaeli's (2003) conceptual model to illustrate that domestic policy adaptation to EU-induced reforms is often shallow and a mere façade.

Other prior literature in the field of politics has identified links between this reform gap and the particular features of the local political system. For example, in delegative democracies the operation of formal institutions is eroded by non-formalized but strongly-operative practices, such as clientelism (O'Donnell, 1994), which "cut across the divide between public and private" (Christiansen \& Neuhold, 2012b, p. 1). The issue of clientelism, and more generally the existence of informal practices, is certainly not limited to delegative democracies (Christiansen \& Neuhold, 2012a). Key aspects of the process and outcomes of political and economic reform initiatives can be explained using the "party patronage" approach (Hopkin, 2006; Kopercky \& Scherlis, 2008; Piattoni, 2001; Roniger, 2004). In broad terms, party patronage refers to the actions of political parties in power to put appointees in key positions (in the civil service as well as various commissions and regulatory bodies), so that government policies and objectives are best served (see Piattoni, 2001). Party patronage constitutes a critical organizational and governmental resource employed by political parties across Europe and elsewhere (Kopercky \& Scherlis, 2008). 
However, the scope of party appointments, as well as the rationale behind it, may vary significantly. In countries with well-established institutional traditions (representative democracies), party patronage may be narrow in scope and political appointments are usually limited to ministerial positions, only to secure the mere existence of party government (Kopercky \& Scherlis, 2008, p. 362). In contrast, in countries with weak institutionalization ${ }^{2}$, in addition to the control of topranking positions, a large number of jobs are supplied as a clientelistic exchange for political support: "this type of patronage is primarily employed ... for more far-reaching clientelistic exchanges ... [W] hat matters, however, is that jobs are primarily utilized as a reward for party or factional allegiance, rather than for any other purposes" (Kopercky \& Scherlis, 2008, p. 363; see also Hopkin, 2006).

A clientelistic political system in delegative democracies means that institutions such as OBs, which in principle should be autonomous organizations, in practice lack independence from the state apparatus, which itself is a prisoner of political parties (Featherstone \& Papadimitriou, 2008; Lyrintzis, 2005, 1984; Papakostas, 2001). Party patronage in delegative democracies systematically undermines the operation of OBs as independent horizontal control mechanisms (O'Donnell, 1994). Lack of independence implies limited ability for an OB to express an objective opinion within its jurisdictional domain, to the extent that such an opinion could be interpreted as undesirable or disadvantageous for the government. In addition, institutions in delegative democracies run the risk of being caught in the cogs of clientelism, state indifference, ineffectiveness and red tape. These interrelated factors might even prevent an institution from dealing with basic organizational issues and developing into a functioning organization.

In short, clientelism and other features of delegative democracies (e.g. poor government effectiveness, regulatory quality and rule of law) limit the possibility of building strong, operative institutions of horizontal accountability, such as OBs, which are nonetheless a key component of the global financial infrastructure that emerged in the 2000s. From a more general viewpoint, these countries lack the ability to produce and apply coherent and consistent policies, thus they exhibit, to varying degrees, poor records of implementing major reforms. This conceptualization of the state is

\footnotetext{
${ }^{2}$ Kopercky and Scherlis (2008) identify a third group of countries in which the number of posts filled by the party is higher and, therefore, the potential control exercised would also be higher.
} 
certainly in contrast with the role of the state in advanced, institutionalized democracies (O’Donnell, ibid.).

This theoretical conceptualization, drawn from literature on politics, of the varying ability of states to deliver on key functions has received broader empirical support in global surveys. For example, Kaufman et al. (2013) report significant variation in key governance indicators, including government effectiveness, regulatory quality and rule of law. More importantly, significant variation also exists in these indicators even among EU member states.

In summary, the theoretical threads on which this article is based suggest that the establishment and development of Anglo-American in conceptualization, OBs should be examined in relation to the dynamics of the political economy of the global economic system. OBs are promoted by the G7/G20 and other powerful global actors as a uniform solution to improve the quality of financial reporting and to help instill stability in a crisis-prone and interdependent global financial system. This need has been so profoundly exposed during the current financial crisis which has shaken the world economy. The proliferation of OBs in the early 2000s rests on the assumption that every country has the capability to successfully establish and operate accounting institutions moulded on Anglo-American governance regimes.

However, the efficacy of local OBs should not be taken for granted, since countries differ in their historical, social, cultural and economic traditions, and these differences, in turn, may condition their ability to introduce systems of effective oversight and related reforms. Thus, the operation of emerging domestic OBs warrants close examination. Countries with a tradition of weak institutionalization (delegative democracies) tend to exhibit significant difficulties in importing reform measures developed in countries with a tradition of strong, operative institutions. The former tend to lack a nexus of horizontal accountability mechanisms, which thus hampers the development of strong OBs. Clientelism, a particular version of party patronage, is a widespread characteristic of political systems in certain European countries (and elsewhere) and is associated with the institutional weaknesses of delegative democracies and their inability to build strong, operative OBs.

\section{Research methods}


This study follows a case study research design (Babbie, 1998; Hussey \& Hussey, 1997; Yin, 2002) and its empirical part, which spans the period 2003-2014, is based on a mix of data sources and triangulation research methodology (Denzin, 1978; Jick, 1979). The data sources include a wealth of publically-available archival material (e.g. minutes of parliamentary debates, parliamentary reports, laws, ministerial decisions, articles in the press and in professional journals, as well as a small number of letters, memoranda and reports submitted by interested parties to the Minister of Economy $^{3}$ ). The written evidence is supplemented with 10 focused, semi-structured, face-to-face interviews. The interviews covered, depending on the interviewee's personal knowledge, a series of issues related to the establishment and performance of ELTE. Semi-structured interviews were recorded and professionally transcribed. Interviewees requested their names not be disclosed in the paper (apart from Minister Alogoskoufis, who made no such request), but agreed to disclosing the description of their post. Furthermore, three interviewees requested that the interview not be recorded and notes were taken instead. Interviewees included: the Minister of Economy (20042008); the Secretary General to the Ministry of Economy (2004-2007); the two chairmen of ELTE (2003-2009 and 2009-2014, respectively); the President of the Institute of Certified AuditorsAccountants of Greece (1993-present), who is also a partner in a large local audit firm; one local, small audit firm partner and two Big-Four audit firm partners; one senior public servant at the Ministry of Economy; and one member of ELTE's Disciplinary Council.

Our study shares limitations inherent to a qualitative methodology. In addition, we acknowledge that one of the authors (referred to in the paper as "Academic") served as a member of ELTE's accounting arm for two years (2005-2007). To reduce the risk of subjectivity and bias, we note that the paper is mostly based on publically-available written evidence, unrelated to the Academic. In addition, all semi-structured interviews cited herein have been conducted by the other co-authors.

\section{The interaction between global and local institutional settings}

\section{The global landscape}

In Europe, public oversight of accounting and auditing emerged as a policy matter in the late 1990s, when the EU embarked on a review of the corporate external audit function, in light of further

\footnotetext{
${ }^{3}$ All empirical sources are available on request from the authors.
} 
integration (European Commission, 1998). This review resulted in the issuing of the Recommendation of 15 November 2000, which viewed the creation of an effective system of public oversight at the state level as an integral part of a single internal market (European Commission, 2001a). Although the Recommendation was non-mandatory, it provided a clear indication of the EU's preference for a system of oversight independent of the profession. It envisaged that such a system would be run by non-professionals, including representatives from the industry, securities regulators and other stakeholders. These EU measures intensified in the early 2000s and eventually culminated in the issuing of the (new) Eighth Directive in 2006 (European Commission, 2006). This piece of EU legislation requires member states to install or upgrade systems of accounting and auditing oversight.

These EU measures reflected developments on the other side of the Atlantic (Davies \& Green, 2008, Malsch \& Gendron, 2011). In the US, following the infamous Enron scandal and the collapse of Arthur Andersen in 2001, the Sarbanes-Oxley Act (US Congress, 2002) led to the creation of the Public Company Accounting Oversight Board (PCAOB), which heralded the end of self-regulation for the accounting profession in the US (e.g. Anantharaman, 2012; Lennox \& Pittman, 2010). The new regulator was charged with audit quality inspections, ending the peer-review system run hitherto by the US profession (ibid.).

It is within this international context that domestic OBs began mushrooming in the early 2000s across the globe, as one means of regulating crisis-prone globalized capitalism (Büthe \& Mattli, 2011; Davies \& Green, 2008; Wade, 2007a). Although the argument that integrated economies require integrated systems of regulation and oversight has received support (Davies \& Green, 2008), OBs are set up and operate at the local, domestic level. Thus, the structure of these emerging systems of oversight, i.e. dispersed OBs embedded within diverse local contexts, is incongruent with the ever-growing integration of the global financial system.

The need to coordinate diverse OBs was recognized in 2006 when national OBs from 18 separate jurisdictions set up a representative organization, the International Forum of Independent Audit Regulators (IFIAR). Membership has only grown to 49 as of 2014, so most UN member states have not yet joined. IFIAR is meant to operate as a platform for coordination, knowledge sharing and 
dialogue among bodies, with no enforcement power over its members ${ }^{4}$ regarding audit quality inspections. At the moment, coordination of national OBs through IFIAR remains rather elementary (Davies \& Green, 2008, pp. 89-91; Humphrey et al., 2009). IFIAR issued seven non-binding ${ }^{5}$ core $^{2}$ principles for its members in April 2011. Similarly to IFIAR, the European Group of Auditors' Oversight Bodies established by the European Commission in 2005 lacks enforcement power ${ }^{6}$, since it is limited to an advisory and coordinating role within the EU.

\section{The local politico-economic and professional context}

As a member of the European Economic Community since the early 1980s, Greece's position within the global politico-economic system has been conditioned by European policies. With regard to accounting and auditing in particular, relevant regulation and practice in the past three decades has largely been shaped by European directives (Caramanis \& Dedoulis, 2011). During the past three decades, successive governments ${ }^{7}$ have pursued further integration of the country into the EU. This effort has entailed a series of liberalization reforms since the early $1990 \mathrm{~s}$, among them the liberalization of the Greek audit market in 1992 (Caramanis, 1999), and culminated in Greece's entry to the euro zone ${ }^{8}$ in 2001.

However, despite improvements in certain financial indicators, concerns have remained about the real growth and development of the economy. For example, Greece has consistently been the worst performer in terms of the criteria set out in the Lisbon Programme (e.g. World Economic Forum, 2004, 2006). Clear signs of an economic slowdown had been apparent before the 2008 financial crisis erupted and the country eventually entered into a deep (and still ongoing) recession in 2009,

\footnotetext{
${ }^{4}$ See https://ifiar.org/About-Us.aspx

${ }^{5}$ See https://ifiar.org/IFIAR/media/Documents/General/Final-Core-Principles.pdf

${ }^{6}$ See http://ec.europa.eu/internal_market/auditing/egaob/index_en.htm

${ }^{7}$ From 1981 to 2012 , the country had been governed by either the socialist PASOK party or the center-right New Democracy party. New Democracy was in power for eight of these years (1990-1993 and 2004-2009). In October 2009 , PASOK returned to power against the background of an intensifying economic crisis. A coalition government has been at the helm since 2012 .

${ }^{8}$ It has been argued, however, that entering the euro zone in 2001 was, to a certain degree, the result of political considerations at the EU level, as well as of creative accounting practices in Greece's financial statistics (e.g. Financial Times, 11 and 30 November 2009).
} 
amid widespread recognition that the financial crisis was a symptom of more serious, structural socio-political problems (e.g. OECD, 2009, 2010, 2011a, 2011b, 2012).

Greece's lingering economic problems are certainly related to the country's reform capacity problems, resulting from its weak institutionalization and clientelistic political system (e.g. Featherstone \& Papadimitriou, 2008). An OECD report (2011b) explicitly ties Greece's problems to the widely-acknowledged weakness of the state apparatus:

Strong measures ... to improve the effectiveness, accountability and integrity of the public administration so that it is "fit for purpose" are a priority, perhaps even the first of the reform priorities facing Greece. Failure to implement a major and integrated public governance reform in Greece is likely to jeopardise the broader reforms required to put Greece back on the path to sustainable growth (ibid., p. 3).

The weakness of the Greek state apparatus and its role as an impediment to progress has been recently highlighted by Jean-Claude Triche, head of the European Central bank (2003-2011), in the context of an inquiry led by the European Parliament into the handling of the Greek crisis by the "troika" (the European Commission, the European Central Bank, and the International Monetary Fund). As Triche (2014, trans.) states: "The state in Greece does not operate the way it should ... [W] hat Greece should do is to continue trying to build a solid state. This is a precondition for the country to succeed ... and for the economy to operate". Kaufman et al. (2013) also capture the weakness of Greek public administration in a global survey, in which Greece ranks at or close to the bottom of EU member states in key governance indicators, including government effectiveness, regulatory quality, and rule of law.

The international developments in accounting regulation of the late 1990s and early 2000s have been repeatedly and explicitly acknowledged by the Greek government as a significant factor in formulating policy regarding the establishment of ELTE (e.g. Greek Parliament, 2003a, 2003b, 2003c). For example, the Minister of Economy Christodoulakis (2001-2004) stated that the government was trying to bring Greece closer to the global SSC system of financial regulation: "We are creating a new institution in order to be in a position to deal with the complexity of corporate audits ... [W] e use the formulae that are available internationally to improve the context in which the markets operate and investors make decisions" (Greek Parliament, 2003c, p. 4.269, trans.). Similarly, the Deputy Minister of Economy Fotiadis openly acknowledged the role of international developments: "[T]he Enron experience has led most countries to initiate reforms in order to 
improve the quality of audits and provide adequate assurances to the investing community ... and this is what we are doing" (Greek Parliament, 2003a, p. 1083, trans.).

However, in addition to international developments, local-level events and conditions in Greece provided further impetus to the introduction of public oversight. As such, these conditions hastened the establishment of ELTE before it actually became an EU legal requirement through the issuing of the new Eighth Directive in 2006. One such major event was the Athens Stock Exchange (ASE) scandal of the late 1990s, which eroded public confidence in financial reporting and the role of the auditing profession. An unprecedented growth in the ASE, which had created market euphoria and involved hundreds of thousands of Greek households, was followed by an intensive downward spiral. The General Index fell from 6,355 to 1,800 points within the space of a few months in the last quarter of 1999 (ASE, 2001). Soon, allegations appeared in the press and in public debates ${ }^{9}$ about the role of key politicians, even of the Prime Minister himself, in the affair and such claims were even raised in the Parliament (Greek Parliament, 2003c; see also Papadimitriou, 2001; Staikouras, 2001).

It is evident that the ASE episode created a legitimation crisis for the government. Under such conditions, tightening regulation or introducing more structural changes has been a state's main response to crisis at various times and locales (Hancher \& Moran, 1989; Malsch \& Gendron, 2011; Zeff, 2003). Indeed, a senior public servant has linked the establishment of ELTE with the ASE affair, suggesting that the creation of the Greek OB "was apparently brought forward by the scandal" (interview, 26 September 2013). During the debate in Parliament on the establishment of ELTE, the sponsor of the bill emphatically suggested that the new regulation was: "an answer to those who argue that the government is somehow related to sleaze and scandals" (Greek Parliament, 2003a, p. 1069, trans.), and Deputy Minister of Economy Fotiadis stated that the government sought to "strengthen transparency" (Greek Parliament, 2003a, p. 1083, trans.) as public confidence in the operation of the market had evaporated.

The final local factor to consider is the division within the Greek auditing profession regarding the introduction of independent oversight, which primarily emanated from a lingering intra-professional

\footnotetext{
${ }^{9}$ The ASE scandal was a major political issue in the elections of March 2000.
} 
conflict. This conflict initially erupted in the late 1970 s between $\mathrm{SOL}^{10}$, a quasi-state auditing organization, and SELE, an aspiring occupational group representing local branches of the big international accounting firms that had been campaigning for access to the statutory audit market (Caramanis, 1999). The profession was eventually liberalized in 1992 through legislation (ibid.). This audit reform entailed the introduction of competition between auditors and the formal unification of the profession as members of international accounting firms gained professional recognition. The reform also abolished SOL and established SOEL ${ }^{11}$, a new professional association, largely organized as a self-regulated professional institute. However, the formal unification of the profession in 1992 failed to end this intra-professional conflict which continued ${ }^{12}$, overtly or covertly, around the issue of the control of SOEL's administration. Related to this conflict, the profession stood divided regarding the proposal for the establishment of ELTE, and particularly regarding the transfer of regulatory and oversight powers from SOEL to the new OB. The Big-Four and international second-tier firms openly supported the reform, while resistance mostly came from SOL SA, the largest (local) audit firm, supported by the Economic Chamber of Greece $\left(\mathrm{OEE}^{13}\right)$, a legal, compulsory trade association of all graduates in the broader field of economics, including business accountants. Thus, the divided profession, apparently involved in the stock exchange scandal, had a significantly reduced capacity to resist reform (Caramanis, Dedoulis, \& Leventis, 2010).

The deep divide and the power relations within the profession were summarized in a letter to SOEL's Supervisory Council, sent by a partner of a second-tier international audit firm shortly after the government announced its plan to set up ELTE:

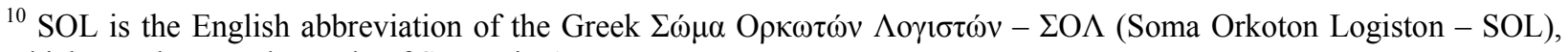
which translates as the Body of Sworn-in Accountants.

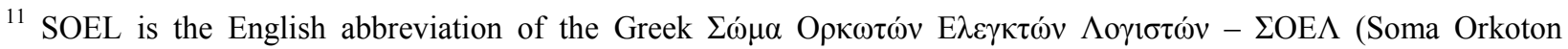
Elegkton Logiston - SOEL), which translates as the Institute of Certified Auditors - Accountants.

12 There was also an abortive attempt to reverse liberalization when PASOK returned to power in 1993 (see Caramanis, 2002, 2005).

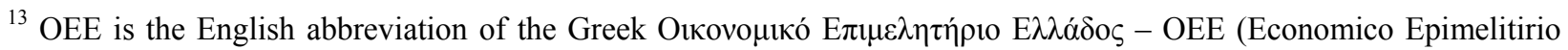
Ellados - OEE), which translates as the Economic Chamber of Greece. OEE was established by the (PASOK) government in the early 1980s as a state-corporatist institution and has traditionally been an arena for party competition and clientelism. All practicing statutory auditors, business accountants and tax consultants must have OEE membership. Other membership comes from tax office and banking sector employees. OEE is still capable of exercising some political power, emanating from its membership, which amounts to around 90,000 individuals. However, it has failed to have any significant impact on accounting and related matters (Caramanis, 1999, 2005).
} 
$[\mathrm{T}]$ he Greek profession is characterised by an extreme concentration of power in very few audit firms ... in practice, two blocks have been formed in the profession. The one that has all the power in the organs of administration and the other that is seeking to bring it into balance. It is this antithesis that has created many problems in the internal operation, status and the public image of the profession (Second-tier partner, 2002, trans.).

Following the 1992 reform, the great majority of SOL members established the audit firm SOL $\mathrm{SA}^{14}$ under the leadership of "Unileader" (Caramanis, 2002) - the most important of the dramatis personae in the Greek accounting profession in the past two decades. Unileader, a charismatic extrade unionist of SOL and middle-to-senior member of PASOK, also served as Secretary General (1996-2000) of the Ministry of Economy and, for two terms, was President of the OEE during the late 1990s and early 2000s. The formal unification of the profession, however, did not end this intra-professional conflict. It continued, explicitly or implicitly, as SOL SA attempted to reverse liberalization following PASOK's return to power in October 1993 (Caramanis, 2002, 2005). Eventually though, the intra-professional conflict seemed to abate, and a modus vivendi between the conflicting groups was achieved, subsequent to SOL SA's utterly unsuccessful attack on liberalization in the late 1990s. Following this development, Unileader focused on consolidating his control over SOEL, which is funded through a legally-sanctioned $2 \%$ annual membership charge on audit fees. Taking advantage of the one member-one vote system of the profession, he has uninterruptedly been the elected President of SOEL since the early 1990s (he was re-elected in April 2012 for another three-year term of office).

In summary, global influences and pressures (i.e. the EU guidelines and the precedent set by the PCAOB) along with local events (the ASE scandal and intra-professional conflict) created a unique trajectory, conducive to the emergence of a local accounting and auditing OB independent of the profession, well before it became a legal EU requirement. However, the delegative characteristics of Greece created a rather gloomy outlook for the prospect of a truly effective and independent accounting and auditing OB.

\section{The parliamentary debate: rhetoric on independence and concerns about clientelism}

\footnotetext{
${ }^{14}$ SOL SA is by far the largest audit firm in Greece, at least in terms of staff. As of 2010, it accounted for almost onethird of SOEL's membership (all ranks included) which, in the highly-politicized Greek context, is widely believed to give SOL SA significant bearing in the political centers of power.
} 
The debate in Parliament on the establishment of ELTE ${ }^{15}$ began in spring 2003 (Greek Parliament, 2003a, 2003b, 2003c). The minutes of this debate provide useful insights into the clientelistic nature of Greek politics, the prevailing perceptions among politicians and the institutional impediments to the independence of "independent" authorities. The proceedings reveal that the risk of creating an impotent institution under government control in Greece was neither unforeseeable nor unforeseen, as shown during the debate on the bill in Parliament.

The need to ensure that ELTE would not fall victim to party clientelism and ineffectiveness, a quintessential characteristic of the Greek public sector, was openly acknowledged by Christodoulakis (Minister of Economy 2000-2004) during the debate in Parliament: "[O]ur purpose is only one: to make the system for overseeing financial audits more transparent, more rigorous and to bring it away from the operation of the state, so that it will be able to adapt to international developments and will be capable of overseeing companies and inspecting auditors" (Greek Parliament, 2003c, p. 4269, trans., emphasis added). Yet he insisted that the Ministry maintain overall control over the new institution, even on technical accounting matters: "[T] he deliberations of ELTE shall be signed by the Minister of Economy" (Greek Parliament, 2003c, p. 4.269, trans.).

Several speakers in the parliamentary debate, across the political spectrum, emphasized ELTE as being under the direct control of the incumbent Minister of Economy. The Member of Parliament (MP) and Shadow Minister of Economy Alogoskoufis ${ }^{16}$ expressed concerns that the creation of ELTE was an opportunity for the government to create posts for its political friends and allies (Greek Parliament, 2003b). Moreover, MPs from political parties on the left argued that, though the law secured independence from the profession, "ELTE lacked even a semblance of independence from the government" (Greek Parliament, 2003c, p. 4259, trans.), underscoring the lack of accountability to Parliament (Greek Parliament, 2003b, 2003c). These MPs, however, extended their criticism to New Democracy: "[W]hile PASOK is seeking full government control over

\footnotetext{
15 The government had announced its plan to establish an accounting and auditing OB and end self-regulation in July 2002, when it published a draft bill for the creation of ELTE (Kerdos, 2002; Ministry of Economy, 2002). A long consultation period ended in March 2003 when the bill was introduced to Parliament, amid fierce and concerted protest from SOEL and OEE. The bill was eventually voted for in May 2003 (Government Gazette, 2003).

${ }^{16}$ Alogoskoufis became Minister of Economy when New Democracy won the 2004 elections. He played a key role in the developments in Greek accountancy in the late 2000s, as we explain subsequently.
} 
accountancy, New Democracy is essentially supporting the bill, as they expect to take political advantage of the new institution if they return to power" (Greek Parliament, 2003a, p. 1077, trans.).

Overall, the debate in Parliament revealed a more general lack of trust in public authorities (which are normally presumed to be independent of government and party-political influences and pressures) as a precondition for the smooth functioning of the free market economy (O'Donnell, 1994). It is indicative that, when the Chairman of the Standing Committee of the Chamber announced that the heads of the Capital Markets Commission and the ASE (traditionally devoted government appointees) had been invited to express their views on the establishment of ELTE, MP Alogoskoufis a priori discredited their testimony and suggested that there was no need to invite them because "on the basis of past experience [they] come to the Parliament only to support the government's views. We shall not learn anything more than what the government and the Minister will tell us" (Greek Parliament, 2003a, p. 1068, trans.). He also explicitly recognized the issue of state ineffectiveness:

The question of the credibility of financial audits is not only a matter of institutions and legislation ... [W] e already had [institutions that did not work and] adequately strong legislation which was not enforced in practice and this resulted in the serious problems of the Athens Stock Exchange [the 1999 scandal] ... [W]e shall vote for the bill because we want to indicate that ... there is a need for more effective audits and more reliable financial statements ... particularly in state-controlled organizations (Greek Parliament, 2003c, p. 4264, trans.).

The issues of clientelism and lack of true independence of OBs from the government were most explicitly captured by MP Lafazanis thus:

The independence of "independent" authorities is a mockery ... You appoint hangers-on to various posts, you name them independent, and then [when things go wrong] you come to say that they have failed and put the blame on them so that you remain protected from criticism. I would prefer, Mr Minister, that you personally have the political responsibility [for overseeing corporate auditing] (Greek Parliament, 2003c, p. 4259, trans.).

However, regardless of any arguments during the debate in Parliament, senior politicians (at least when in power) showed clearly negative attitudes toward truly independent authorities outside the control of the political system, an observation in congruence with O'Donnell's theorization of delegative democracies (1994). As the Secretary General (2004-2007) put it in an interview well after he left office: "Ministers tend to have the view that independent authorities should be at an 
arm's length ... [They] should be independent but not too much so" (interview, 14 July 2010, trans.). That is, ministers want to maintain control over independent authorities. The way the Minister of Economy (2004-2009) under New Democracy rationalized this attitude against truly independent bodies is illuminating:

There are two kinds of risks associated with independent authorities. Either they will not do the job they are established for, or they will be overactive, causing problems for the operation of the market ... [in Greece and] ... they are in a position to hold the Minister to ransom ... and blackmail the government ... because they have all the information and the Minister is very vulnerable to adverse publicity (interview, 14 July 2010, trans.).

\section{The establishment of ELTE: subjugating the new OB to government control}

The Greek OB was eventually established by Law 3148/2003 (Government Gazette, 2003), in May 2003 (the appendix presents the time line of major events in the history of ELTE since July 2002, when the government announced its decision to establish an accounting and auditing OB). Following the international trend (EU guidelines and the PCAOB precedent), the Law secured the independence of ELTE from the profession.

Formally, ELTE was set up as a public sector legal entity and its mission is to "promote transparency in the operation of business enterprises through accounting standardization, and to ensure the quality of corporate audits" (article 1 of the Law, trans.), and to act as the government's formal advisor on accounting and auditing matters. ELTE is funded by audit firms through a $1 \%$ levy on total audit fees ${ }^{17}$, which secures the availability of necessary financial resources.

As figure 1 shows, ELTE is headed by a chairman and two vice-chairmen, who constitute its powerful Executive Committee. The chairman and one vice-chairman are selected by the Ministry of Economy and the second vice-chairman is nominated by $\mathrm{OEE}^{18}$, whose leadership at the time was controlled by the governing PASOK. All appointments require confirmation from Parliament. ELTE's administrative structure is supplemented by a seven-member Administrative Council, comprising three members of the Executive Committee and four other individuals nominated by the

\footnotetext{
${ }^{17}$ This, as of 2010, amounted to almost $€ 2 \mathrm{~m}$ per annum in total revenue for ELTE.

${ }^{18}$ The OEE gained the right to nominate one vice-chairman of ELTE as a result of its electoral power and effective political mobilization during the debate in the chamber (see Greek Parliament, 2003a, 2003b, and 2003c).
} 
Bank of Greece, the Hellenic Capital Markets Commission, the Confederation of Greek Industries, and the accounting profession ${ }^{19}$ (SOEL).

Figure 1. The administrative structure of ELTE

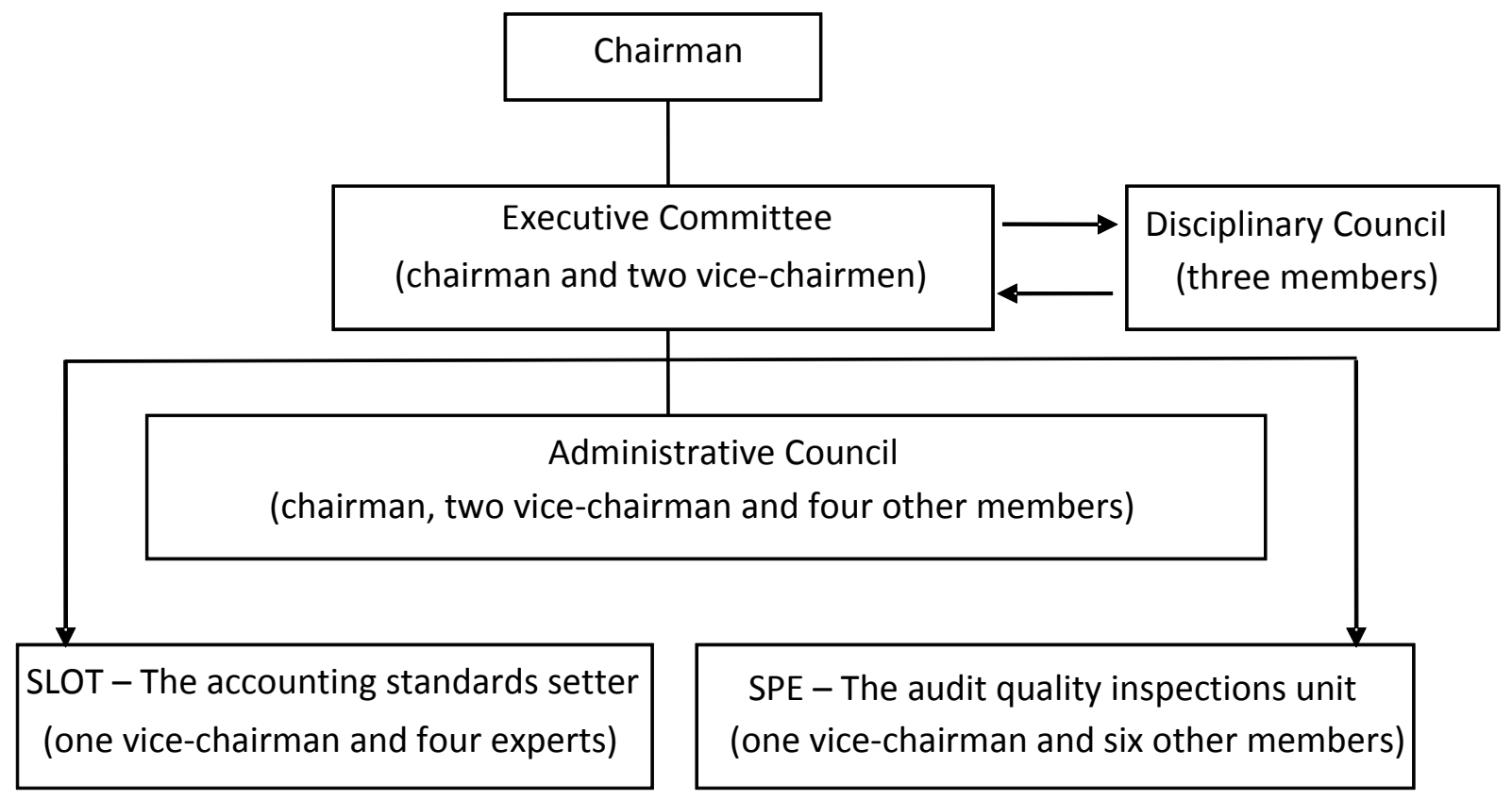

Under the umbrella of ELTE, two organs were created. The first is SLOT $^{20}$ (Accounting Standardization Committee), which comprises four accounting experts appointed by the Ministry of Economy and is headed by one of ELTE's two vice-chairmen. The second is SPE $^{21}$ (Quality Inspections Committee), which is a seven-member committee headed by the second vice-chairman of ELTE. The remaining members of SPE include a senior judge, one member of SLOT and four other individuals nominated by the Bank of Greece, the Hellenic Capital Markets Commission, SOEL, and the Ministry of Economy. SPE's main responsibility is the management of a peerreview-based quality inspection system that was to be introduced.

\footnotetext{
${ }^{19}$ The initially-submitted Law did not provide for representation of the profession in ELTE. However, political pressure during the discussion in Parliament gave SOEL one seat on ELTE's Administrative Council (see Greek Parliament, 2003a, 2003b, and 2003c).

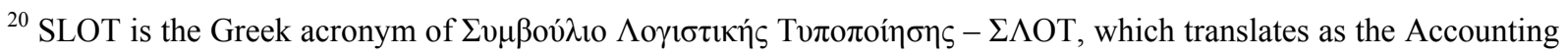
Standardization Committee.

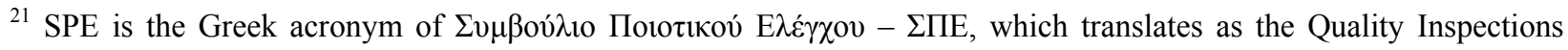
Committee - SPE). The appointment of SPE members is controlled by the Minister of Economy.
} 
In addition to directly appointing the three heads of ELTE and the members of SLOT, the nominations for membership of ELTE's Administrative Council (four) and of the Quality Inspections Committee (five) require formal approval from the Ministry of Economy. Furthermore, the Ministry of Economy exercises oversight of ELTE's operations, determines the remuneration of its senior staff, and approves the appointment of administrative personnel. Even ELTE's regulatory decisions on technical issues are subject to approval by the Ministry of Economy. Finally, Law $3148 / 2003$ removed the disciplinary power of SOEL and provided for the establishment of a new system of disciplinary arrangements ${ }^{22}$, independent of the profession, which would operate in parallel with ELTE. The members of the Disciplinary Council were to be appointed by the government. Furthermore, auditor independence was to be strengthened through the introduction of provisions on various issues (e.g. auditor rotation, employment of audit staff by the client, consulting services to audit clients).

The formal passing of Law 3148/2003 and the establishment of ELTE as the first OB in the history of Greek accounting and auditing naturally created expectations of much-needed improvements in Greek financial reporting ${ }^{23}$. However, given the deeply politicized nature of the Greek state and the lingering ineffectiveness of public administration, the close control of ELTE by the government apparently gave cause for concern from the outset, and called into question whether ELTE as an institution would in practice play the vital role for which it had formally been established. We turn to this issue in the next section.

\section{ELTE in a state of inertia}

ELTE was envisaged to play a key role in ensuring much-needed transparency and confidence in financial reporting. This would be achieved by improving the quality of corporate audits through the introduction of a system of audit quality inspections. However, since its inception in May 2003, ELTE has, in practice, fallen into an essentially dormant state with regard to improving transparency and confidence in financial reporting. ELTE's situation was acknowledged by its

\footnotetext{
${ }^{22}$ The bill initially provided for severe monetary fines for errant auditors and audit firms, but these penalties were significantly softened in the final text of the law, as the profession stood united against them.

${ }^{23}$ According to academic research, Greece has a leading position in earnings management internationally (Christensen et al., 2012; Leuz et al., 2003; Osma \& Pope, 2011).
} 
chairman (since 2009) in an interview with the influential quarterly Accountancy Greece, issued by SOEL for its membership:

As you know, since its establishment in 2003, ELTE has been in a state of inertia ... understaffed, without [proper] offices, incapable of performing its duties and, most importantly, unable to conduct the audit quality inspections required by legislation since 2003 ... It is imperative that the Authority be staffed with qualified personnel as a matter of urgency (Refenes, 2011, p. 29, trans.).

The poor state of ELTE was documented in an academic survey of auditors and corporate financial executives (Caramanis \& Papadakis, 2008). The survey, which attracted significant media attention, revealed that Greek oversight authorities were in need of significant improvements in several respects, including: reliability, transparency, staffing, and independence from political and economic centers of power (e.g. Kerdos, 2008; Kourkouta, 2008; Naftemporiki, 2008). The headline of the newspaper Kerdos (2008, p. 14, trans.) read: "The deficiencies of the oversight authorities cast doubt on the benefits of the introduction of IFRSs". ELTE's poor state of affairs was also evidenced by its development of a web page as late as spring 2009, six years after its establishment; a web presence had been agreed on early in 2005, since it was considered a key factor in effecting change and ensuring transparency and accountability (SLOT, 2005).

The failure of ELTE to perform its duties over the years has been indicated in internal documents prepared by the Academic member of SLOT and a retired senior judge-member of the SPE and submitted to the Ministry of Economy (Academic, 2006, 2007, 2008; Retired Judge, 2006a, 2006b). ELTE's deplorable position has also been highlighted in two parliamentary questions raised by MPs Tatoulis (2009) and Katseli (2009). In her question, Katseli particularly stressed that "ELTE ... with a leadership appointed by the government has fallen victim to the pathogenesis of Greek public administration" (Katseli, 2009, p. 2, trans.). The Secretary General 2004-2007 and the Minister of Economy (2004-2008) also both acknowledged that ELTE had failed to improve Greek accounting and audit practice and, in retrospect, implicitly expressed their regret for not taking appropriate measures while in power (both interviewed on 14 July 2010).

ELTE's inaction is most evident with regard to quality inspections. Following the filling of the SPE posts in March 2006, ELTE initiated the organization of the first audit quality inspections in the history of Greek auditing in July 2006, three years after its establishment. However, this attempt 
utterly failed: "[I]t became clear that we did not have a safe legal framework to proceed, we did not have our own audit quality inspectors ... it would be a mockery to perform inspections under such conditions" (interview with the Chairman of ELTE 2003-2009, 26 September 2013, trans.). Two years after this incident, the government eventually passed Law 3693/2008, which, inter alia, abolished the peer-review system and provided that ELTE would appoint its own audit quality inspectors. However, ELTE did not have the authority to proceed with filling the posts of quality inspectors, as recruitments were subject to the Ministry's approval. It took one year (July 2009) for ELTE to receive permission from the Ministry of Economy to appoint five qualified members of staff for the audit quality inspections on a one-year employment contract (ELTE, 2009). Using the limited human resources available, ELTE was eventually able to complete the first audit quality inspections as late as April 2010, seven years after its inception (ELTE, 2010). The main findings of these inspections were presented at a public event on 14 April 2010. ELTE's chairman publicly admitted in his speech that ELTE had adopted a largely "educational" approach and no disciplinary action was taken. He made clear though that ELTE would exercise disciplinary action against any deviant auditors in the next round of inspections.

However, the work contracts of ELTE's inspectors expired in spring 2010, and, as no permission for new appointments had been granted by the Ministry of Economy, ELTE had insufficient human resources even for minimum operations. Yet Greece still needed to comply with the requirement of the Eighth Directive for audit quality inspections on a regular basis (interview with the Chairman of ELTE 2009-2014, 26 July 2013). To deal with this problem, shortly thereafter an arrangement was made between ELTE and SOEL, with the permission of the Ministry of Economy, according to which SOEL appointed two inspectors who were then seconded to ELTE (interviews with the President of SOEL, 19/07/2013; Chairman of ELTE 2009-2014, 26/07/2013). The two individuals would mainly deal with urgent investigations ordered within the context of judicial procedures, following major, or sometimes more minor, auditing scandal (interview with the Chairman of ELTE 2009-2014, 26/07/2013).

Nevertheless, ELTE's performance eventually came under legal scrutiny. On 5 April 2012, the public prosecutor for economic affairs ordered an investigation into ELTE's apparent inaction by the Internal Audit Service of Public Administration (Kousoulos \& Vlachoutsakos, 2012). The judicial investigation was provoked by written allegations by individuals (investors claiming 
financial losses as a result of ELTE's inaction) that had been submitted to the Ministry of Economy and various judicial authorities (ibid.). The report of the Internal Audit Service of Public Administration found that ELTE had in fact failed to perform its responsibilities, but attributed this to lack of staff (interview with the Chairman of ELTE 2009-2014, 26 July 2013).

In January 2013, ELTE received permission from the Ministry of Economy to outsource the implementation of audit quality inspections, since public sector appointments had essentially been banned since 2010 due to the financial crisis. The contract was awarded to SOEL, the professional organisation representing the auditing profession, which appointed six individuals from the relatively junior staff of audit firms on fixed-term contracts (interview with the Chairman of ELTE, 26 July 2013). The arrangement was in clear violation of core principle 5 of IFIAR (2014), of which ELTE is a member. According to Principle 5:

Audit regulators should have arrangements in place to ensure that inspection staff members are independent of the profession. These arrangements will, as a minimum, include ensuring that staff members should not be practicing auditors or employed by or affiliated with an audit firm, and that the arrangements are not controlled in any form by a professional body.

The problem with the IFIAR requirement was acknowledged by the Chairman of ELTE who explained that "in the prevailing political circumstances, there was no other option ... this was as far as we could go" (interview with the Chairman of ELTE, 26 July 2013, trans.). Furthermore, questions have been raised as to the technical ability of the staff appointed to perform effective quality inspections of the audit files of large and complex organizations such as banks and insurance companies (interviews with two Big-Four audit firm partners, 6 and 7 September 2013). This is another violation of IFIAR's principle 5 that inspection staff be of appropriate competence. The Chairman of ELTE 2003-2009 voiced his concerns thus: "I do not know the inspectors personally, so I cannot comment on their technical competence. But there is an obvious question as regards the credibility of inspections performed by staff members appointed by the profession ... at the very least they lack the appearance of independence" (interview, 16 September 2013, trans.).

The performance of audit quality inspections had the backing of the profession, in an attempt to deal with an acute drop in audit fees in the middle of the ongoing financial crisis (interview with the President of SOEL, 27 July 2013). Even before the advent of the crisis in 2008, a survey found that a significant majority (two-thirds) of auditors supported quality inspections as a means of 
maintaining audit fees at a satisfactory level (Caramanis \& Papadakis, 2008, p. 47). A senior partner in a Big-Four firm put it thus: "We do believe that audit quality inspections are in the interests of the profession ... to improve credibility and as a safeguard against unfair competition" (interview, 6 September 2013, trans.). No such inspections had yet been completed as of July 2013, and ELTE still appears to remain in an essentially dormant state ten years after its establishment.

The inertia of ELTE has been complemented by inaction on the part of the profession's Disciplinary Council, in which ELTE plays a de facto coordinating role. During the past decade, four cases (alleged audit scandals) have been referred to the council by ELTE (two in 2011 and two in 2013), but none had been concluded as of April 2013 (Refenes, 2013). A member of ELTE's Disciplinary Council gave his insight into the apparent inaction thus:

One key obstacle to the effective operation of the disciplinary function is the fact that we are essentially unpaid and on top of that there is no legal immunity or other protection. If we impose a penalty on an audit firm, we run the risk of facing claims for damages or even criminal charges on the part of the audit firm ... and the legal environment is quite vague. It seems to me that nobody really cares about what the Council does or does not do, or what needs to be done to enable the Council to perform its duties properly. (interview, 14 July 2013, trans.)

The inertia of ELTE and the absence of an operating Disciplinary Council have been vividly noted by a senior Big-Four partner: "ELTE has done nothing at all ... has performed no audit quality inspections, although it should have. the Disciplinary Council has not been functioning ... we know there are cases which have been pending for a very long time ... Unfortunately, we have missed the opportunity to improve the status of the profession ... and you know we pay for ELTE every year as required by law" (interview, 7 September 2013, trans.).

\section{Explaining inertia: institutional features of a delegative democracy}

The establishment of ELTE as a public sector entity under the supervision and control of the Ministry of Economy firmly anchored the new OB to the Greek state apparatus. This lack of independence has implications that go beyond the ability of an OB to express a view that might put the incumbent government in an awkward position. As the case of the Greek OB shows, lack of independence from the government (and general lack of autonomy) in a political system of governance permeated by a tradition of party politics and clientelism, increases the risk of being caught in the cogs of state indifference, red tape, and ineffectiveness (O'Donnell, 1994). In practice, 
these interrelated factors include the inability of the OB to deal with basic organizational issues and develop into a functioning institution.

The Chairman of ELTE 2003-2009 commented on the independence of ELTE from the government thus:

As I understand it, at the core of EU policy in relation to oversight has been independence from the profession and this has been secured ... In retrospect, independence from the Greek Ministry of Economy is an equally important issue ... I had talked on a number of occasions to the Minister of Economy regarding the need to ensure ELTE's independence from the government; I had been reassured that appropriate action would be taken but the issue remains unresolved ... ELTE is still a public sector legal entity under the control of the Ministry (interview, 16 September 2013, trans.).

Next, we examine the modes that hampered the development of institutions of horizontal accountability.

\section{Party politics and clientelism}

In Greek political tradition (Featherstone \& Papadimitriou, 2008; Lyrintzis, 2005), the appointment of (key) staff is mostly, though not exclusively, made on the basis of political affiliations rather than merit and capacity to deliver:

In my experience, loyalty or networking is the key factor for appointments to public posts. We often see unqualified and indifferent people get key posts. It is loyalty and networking rather than personal aptitude and knowledge that count. There is a golden rule and in the past some appointees have learned it the hard way: do not attempt to make waves if you want to keep your job ... and it pays off ... it secures a significant source of income (interview with a certified auditor with considerable experience as a member of various accounting regulatory and oversight authorities, 8 September 2008, trans.)

A member of ELTE's leading elite offered his view on the role of party affiliations in filling posts in ELTE thus: "I think, to a significant extent, when ELTE was established the logic of the government was to cover the [EU] requirement and ... to accommodate some of the party people" (interview with the Chairman of ELTE 2009-2014, 26 July 2013, trans.).

Party political affiliations have consistently played a significant role in filling key positions in ELTE (interview with a senior public servant at the Ministry of Economy, 26 September 2013). An 
active certified auditor and senior partner ${ }^{24}$ in a Big-Four audit firm was appointed as the first chairman of ELTE in August 2003; and a senior member of the OEE, who was a unionist affiliated with the governing PASOK party, was appointed as vice-chairman and head of SPE. The post of the second vice-chairman (head of SLOT) was filled by an elderly independent accountant and key figure in the old Greek accounting establishment (interview with the Chairman of ELTE 20032009, 16 September 2013). The two vice-chairmen did not subscribe to the idea of introducing major reforms to Greek accounting and auditing (interview with the Chairman of ELTE 2003-2009, 16 September 2013).

Significantly, the government showed no interest in filling the remaining posts in ELTE. In March 2004, PASOK lost the elections and the center-right New Democracy party came into power. Alogoskoufis was sworn in as Minister of Economy, and another person, affiliated with the governing party, was appointed as Secretary General ${ }^{25}$ to the Ministry of Economy. Despite his strong rhetoric in favor of independence from the state during the passing of the Law through Parliament that established ELTE, the new Minister passed article 18 of Law 3301/2004 in December 2004, which brought ELTE under even closer government control and abolished OEE's and SOEL's rights to nominate members to ELTE's organs of administration (Government Gazette, 2004). According to the new Law, the government would appoint two public servants from the Ministry of Economy as the two vice-chairmen of ELTE, and one member of its Administrative Council would be nominated by the Federation of Industries of Northern Greece ${ }^{26}$.

The government (New Democracy) changed the composition of ELTE's Administrative Council in early February 2005 (Naftemporiki, 2005). The two vice-chairmen initially appointed by PASOK were replaced by two public servants from the Ministry of Economy, both of whom were openly associated with the governing party (interview with the Secretary General of the Ministry of Economy 2004-2007, 14 July 2010). In particular, at the time of appointment, one of the two individuals was serving as the Director of the Minister's Political Office, a position he continued to

\footnotetext{
${ }^{24}$ On accepting his appointment, this individual formally went on a voluntary suspension from practice.

${ }^{25}$ The Secretary General formally oversaw the operation of ELTE, but the power now rests with the Minister who is the real decision maker. The individual concerned maintained his post until March 2007, when he moved to another post. He was replaced as Secretary General by a retired senior public servant of the Ministry of Economy.

${ }^{26}$ According to a senior public servant, this was a request by the then Deputy Minister of Economy who was elected in Thessaloniki, the largest city of Northern Greece (interview, 26 September 2014).
} 
hold for one and a half years after his appointment (interview with the Secretary General of the Ministry of Economy 2004-2007, 14 July 2010). The chairman of ELTE maintained his post.

After he left office, the Minister of Economy (2004-2008) under New Democracy acknowledged the influence of clientelism on ELTE and explained the government's policy on filling key positions in ELTE thus: "[The Chairman of ELTE] was not a political friend of mine, I did not know him personally. He was a professional man, knowledgeable in accounting and auditing. Certainly, he had been appointed by the previous government [but] I was of the view that he should stay to give the message that the state has continuity" (interview, 14 July 2010, trans.). However, he admitted that the two vice-chairmen were party devotees, "but what is important is that the Chairman was not ... ideally no one should be ... but, you know, a vicious precedent [clientelistic appointments] has long been set in public administration" (interview, 14 July 2010). Thus, keeping the chairman of ELTE, who had been appointed by the previous government, also served legitimation purposes.

In January 2009, Alogoskoufis was removed, and Papathanasiou became the new Minister of Economy. The change of minister would, in the Greek political tradition, ordinarily raise expectations of a change in ELTE's leadership. Indeed, the new Minister of Economy replaced two of the three members of ELTE's Administrative Council. On 3 April 2009, he appointed a Professor of Finance as chairman and a retired Big-Four partner as vice-chairman of the SPE (the audit quality inspection unit of ELTE) (Government Gazette, 2009). No further changes in the leadership of ELTE have taken place up to the time of writing this article.

Clientelism and weak institutionalization are also evident in recurring incidents of a conflict of interest regarding ELTE's leading elite. In July 2007, the chairman of ELTE (2003-2009) was appointed non-executive director to a "regulatoree", a large listed Greek bank (see Express, 2007), and a year later he became chief of the bank's General Directorate - Internal Control according to the bank's press bulletin of 31 July 2008. In a similar vein, in July 2008 the vice-chairman of ELTE (the head of SPE from 2003-2009) and one of the Minister's close associates became chairman and chief executive officer of a large pension fund whose financial statements are subject to statutory audit. Another incident occurred in the early 2010s when the (new) vice-chairmen of ELTE (2009- 
present) accepted an appointment with the audit committee of a major listed Greek bank ${ }^{27}$ and a second appointment as chairman of the board of directors at an insurance company ${ }^{28}$.

These instances of apparent conflicts of interest have been discussed within professional circles and at the Ministry of Economy (interview with a retired senior public servant of the Ministry of Economy, 26 September 2013). Eventually, these issues were published in the press ${ }^{29}$ (e.g. To Vima, 2009) and provoked parliamentary questions (Katseli, 2009; Nikolopoulos, 2014; Tatoulis, 2009). These conflict of interest incidents do not apparently violate Greek law but certainly constitute a severe violation of the independence requirements of OBs (IFIAR, 2014).

\section{State indifference and ineffectiveness}

Against the backdrop of party politics and clientelism, the risk of ELTE being affected by state indifference and ineffectiveness became evident. ELTE was infected by the "deeply rooted ... culture of inertia, slackness and laxity [within the Greek public sector] ... If making or implementing a decision is delayed, nothing bad will happen ... the ship will not sink ... you know, it has taken some ten years for the Greek Capital Markets Commission [formally established in 1990] to start producing some results" (interview with the Secretary General to the Ministry of Economy 2004-2007, 14 July 2010, trans.). The Chairman of ELTE (2009-2014) also emphasized that, "the state, whatever we mean by this, has been a serious obstacle ... It has really inhibited the development of ELTE (interview 26 July 2013, trans.). Our research has indeed identified a chronic lack of active interest on the part of the Ministry of Economy in relation to the effective operation of ELTE: "Although there had been pressure from market forces [to improve accounting and audit practice] ... [a]ccounting has essentially been a second, if not third, priority issue for the Ministry" (interview with the Secretary General to the Ministry of Economy 2004-2007, 10 July 2010, trans.). The chronic lack of interest in ELTE on the part of the government was highlighted by both chairmen of ELTE, 2003-2009 and 2009-2014 (interviews, 26 July 2013 and 16 September 2013 respectively).

\footnotetext{
${ }^{27}$ See the 2010 financial statements of the National Bank of Greece, p. 170.

${ }^{28}$ See http://www.interasco.gr/hilton.asp (in Greek).

${ }^{29}$ This adverse publicity might have played a role in the change in ELTE's leadership in April 2009.
} 
The state's indifference is also evident in the delay with which the government filled various posts in ELTE. Although the three heads of ELTE's Executive Committee, along with the remaining four posts in its Administrative Council and one receptionist-secretary, had been appointed by the end of August 2003 (Naftemporiki, 2003), the filling of the positions in SLOT (the accounting standardization committee) took place in February 2005 (Government Gazette, 2005); and the appointment of members of SPE (the audit quality inspections committee) was delayed until March 2006 (Ministry of Economy, 2006), three years after the establishment of ELTE. Yet these appointments were clearly essential even for the most basic operations of ELTE. At times, the proper functioning of ELTE has been derailed by inefficiency in the operation of other state institutions: "[I]t took some 20 months for the Council of the State [the highest civil court] to approve the rules and regulations of ELTE, [which include provisions and bylaws] essential for providing us with some legal security for the decisions we make" (interview with the Chairman of ELTE 2009-2014, 26 July 2013, trans.).

Underlying the indifference on the part of government, a view commonly held in Greece is that, regardless of any formal requirement, inaction or avoiding tough issues secures extended terms for officeholders by reducing any adverse reaction or "political cost", i.e. the estrangement of political friends and supporters (interview with the President of SOEL, 19 July 2013). Furthermore, inaction is encouraged by the complexity of public administration rules and a subtle system for avoiding responsibility. For example, certain issues, such as the supervision of ELTE, may fall under the jurisdiction of the Secretary General, who is formally overseen by the Minister: " $[\mathrm{M}] \mathrm{y}$ directions to the Secretary General have been crystal clear, that he should perform the responsibilities that legally belong to him" (Minister of Economy 2004-2008, interview, 10 July 2010, trans.). However, in practice:

Greece's political and public administration systems are built in such a way that even minor issues must have the approval of the Minister ... ministers usually like to keep control while the bureaucracy tend to avoid taking responsibility. They [the bureaucracy] keep asking for directions from the Minister or the Secretary General to appear agreeable, and yet they write documents and decisions in such a way so that they cannot be held responsible ... the public administration does not work in the right way and this is an issue for the political system to sort out (interview with the Secretary General 2004-2007, 10 July 2010, trans.). 
Politicians may pass the buck simply by stating a lack of briefing or understanding of the issues involved and invoking the role of bureaucracy: "I have always passed any issues raised referring to problems with ELTE straight on to the competent services of the Ministry" (interview with the Minister of Economy 2004-2009, 14 July 2010, trans.). Then, an unwritten rule in Greek public administration essentially insulates politicians from criticism. That is, recommendations by subordinates to the Minister are formally submitted only when they have a green light (from the Minister) to do so (interview with the Secretary General 2004-2007, 10 July 2010). Thus, the Minister can always legitimize his decisions by arguing: "I have always acted upon the formal recommendations of the services of the Ministry" (interview with the Minister of Economy 20042009, 14 July 2010, trans.).

Furthermore, as a public sector body, ELTE has been affected by the austerity measures taken as a result of the ongoing economic crisis. Indeed, ELTE remains subject to the provisions of the memorandum(s) of understanding, agreed on since 2010 between Greece and its lenders (the troika of the European Central Bank, the European Commission, and the International Monetary Fund). These measures, in view of the severity of the country's financial crisis, have imposed significant reductions in salaries and restrictions on appointments within the public sector. The austerity package that followed the memorandum of understanding has been applied across the entire Greek public sector.

The leadership of ELTE tried to convince the government to exempt ELTE from the restrictions following the memorandum of understanding (interview with the Chairman of ELTE 2009-2014, 26 July 2013), which was confirmed by a senior partner in a Big-Four firm: "I do know that appeals were made to the Minister of Economy, even to the Prime Minister himself and to the troika ... to exempt ELTE ... but they had no effect" (interview, 6 September 2013, trans.). This attempt failed completely because politicians "do not appreciate the role of independent quality inspections for the market ... they do not understand the role of an audit ... they simply do not care ... [I]t is a wider cultural issue which I have been witnessing for decades" (interview with the Chairman of ELTE 2003-2009, 6 September 2013, trans.).

Thus, ELTE has not been given permission by the Ministry of Economy to appoint its own qualified staff, including audit quality inspectors. Even if appointments were allowed, "ELTE will not be able 
to attract suitably qualified staff at the very low public sector salary rates it legally has to follow" (interview with the Chairman of ELTE 2003-2009, 6 September 2013, trans.). As a partner in a Big-Four firm put it:

[I]f one is earning $€ 6,000$ month how would he or she decide to become an audit quality inspector and earn $€ 1,500$ a month? ... From my professional experience over the past 30 years, if you want to neutralize an institution, a function or a process, you just do not provide the required resources ... and it is dead. I do not have concrete evidence that there is necessarily an evil plan worked out but ... (interview, 6 September, 2013, trans.).

Or, as the senior partner put it: "[In other countries] they headhunt to get the best audit quality inspectors ... Here they seem to believe that badly paid civil servants will be able to inspect highly technical work performed by the best auditors ... isn't it a joke?" (interview, 6 September, 2013, trans.).

This section exposes key features of the Greek political system that have inhibited the development of ELTE as an institution. The issue of ELTE's poor performance was directly raised with the Secretary General (2004-2007) and the Minister of Economy (2004-2008) in interviews conducted for this study (both on 10 July 2010). Both interviewees agreed that ELTE has essentially remained in a dormant state. They also provided some explanations as to the government's lack of appropriate action, namely: much-needed structural reforms often take years to produce results, which leads to politicians being reluctant to undertake such long-term projects (their average term of office in the Ministry is usually much shorter and, thus, other politicians may reap the benefits); there is a lack of strong, independent, and reform-minded bureaucracy that could push changes through; and, lastly, there is also a widespread lack of trust among the key participants in public administration. These issues also appeared, quite often and to varying degrees, in interviews conducted with key individuals from the accounting profession and members of ELTE, in the context of this study.

\section{Concluding remarks}

The construction of accounting and auditing OBs at the national level is being promoted as a key component of the global financial architecture that has emerged since the 1990s. Operating within distinctively diverse local political, economic, and cultural contexts, OBs are considered a uniform solution at the global level, aimed at ensuring high-quality financial information to facilitate the 
flow of capital across national borders and provide stability to the interdependent global financial system.

In this article, we examine the creation and operation of an $\mathrm{OB}$ in a local European setting by employing an institutional approach located within the broader political-economy framework of global capitalism (Arnold, 2009b, 2012; Wade, 2007a, 2007b). Consequently, we place emphasis on the interaction between global structural factors, institutions, influences, and pressures (namely the unfolding of the SSC project), and the local socio-political characteristics that condition the establishment and effective operation of OBs at a local (state) level. Our analysis is informed by O'Donnell's (1994) conceptualization of delegative democracy, supplemented by literature on economic and political reform in Europe (e.g. Dyson \& Goetz, 2003; Featherstone \& Papadimitriou, 2008; Radaelli, 2003).

By analyzing a wealth of primary and secondary research material, we illustrate the difficulties and constraints of transplanting and operating OBs which are modeled on the external Anglo-American tradition. Our findings show that deeply-ingrained domestic socio-political characteristics of a delegative nature have indeed inhibited the development and operation of the local Greek OB, as O'Donnell (1994) posits. That is, the newly-established OB has been affected, since inception, by the all-pervasive clientelistic political system, the weaknesses of state apparatus, and the country's reform (in)capacity problems. More specifically, the appointment of ELTE's elite has been decided by successive governments, mainly on the basis of clientelism and political patronage. In addition, ELTE has been under the bureaucratic control of state machinery, despite being privately funded by the profession. Even basic administrative decisions, such as the appointment of audit quality inspectors and administrative staff, need the ex ante approval of the Ministry of Economy.

The Greek OB has remained in a dormant state since its inception. It still lacks appropriate infrastructure and sufficient administrative personnel and has not been granted permission by the government to appoint its own audit quality inspectors. As a consequence, the performance of audit quality inspections has been, at best, erratic. Currently, such inspections can be performed only by outsourcing to the professional body, in contravention of IFIAR's core principle on independence. The disciplinary function appears to have been stalled for years, despite the existence of several pending cases. In short, ELTE as an institution has failed to become a significant decisional point in 
the flow of influence, power and policy in the realm of accounting, which is so important for effecting progress.

Our analysis shows that ELTE's decade-long failure is related to the country's delegative characteristics. The Ministry of Economy has failed to take effective corrective action and there is evidence of distrust or distaste toward truly independent authorities that would act as mechanisms of horizontal control. In a sense, the case of the Greek OB illustrates a form of social homeostasis. In other words, the complex, multifaceted and interdependent system of economic and political power of the country has thwarted the emergence of a truly independent and effective $\mathrm{OB}$ in the accounting realm and, as such, has essentially maintained its equilibrium.

Furthermore, by extrapolation, problems in the effective operation of institutions, including accounting and auditing OBs, seem to extend far beyond the borders of Greece, as literature from the fields of politics and social/economic reforms indicates (e.g. Dyson \& Goetz, 2003). Party patronage, clientelism, institutional weaknesses, and state ineffectiveness are not ingrained features exclusive to Greece. Rather, they occur, albeit in varying degrees and forms, in several other jurisdictions (O’Donnell, 1994). The newcomers to domestic institutional terrains in accounting and auditing are potentially vulnerable to the pathogenesis of local political systems and, in particular, the long historical traditions of party patronage and state ineffectiveness. Thus, while the existing system of oversight appears to be secure against the Scylla of traditional professional control, no care has been taken to deal with the Charybdis of the clientelistic political system, weak institutionalization and state ineffectiveness which are so prevalent in several jurisdictions in Europe and beyond (e.g. Kaufmann et al., 2013).

At a more general level, our analysis draws attention to the structural mismatching between the global nature of the international financial architecture underpinning today's economic integration and the fragmented character of public oversight that operates on a country-by-country basis, embedded within its domestic socio-political and economic constraints. This mismatch raises concerns about the effectiveness of OBs embedded within geographically and socio-politically dispersed domestic institutional contexts.

Our study contributes to current academic literature on accounting regulation. We employ O'Donnell's (1994) conception of delegative versus representative democracy, enriched with 
elements of the broader political economy perspective, to offer a methodological framework for examining the transplanting of externally-induced reforms to diverse local settings. Through the analysis of the Greek OB, we illuminate how local socio-political factors, influences, and pressures condition and eventually limit the effective operation of local OBs. In particular, our case study evidence shows how, in a country exhibiting characteristics of a delegative democracy, the new accounting $\mathrm{OB}$ is assimilated into the local socio-political tradition and preexisting ineffective state structures and remains essentially dormant. This finding lends further support to the literature on social and economic reforms in Europe and elsewhere which argues that, for economic, political, and historical reasons, some countries have not been able to successfully transplant externallydesigned institutions to local settings.

This analysis of the Greek OB has significant implications regarding the suitability of a global system of oversight and should be of interest to global and local policy makers, the academic community, and various other stakeholders in financial reporting. The evidence of our case study questions the underlying rationale of pursuing stability in the global, complex and interdependent financial system through the instigation of domestic OBs modeled on Anglo-American traditions and operating in diverse national environments. We demonstrate that the establishment of accounting and auditing OBs does not automatically translate into concrete benefits to financial regulation and the quality of financial reporting. Structural weaknesses at the local level, and the socio-political fabric and power relations underlying them, result in weak and ineffective local OBs. As a result, material reforms needed at the local level fail to materialize, and imbalances and inequalities among states in the global landscape are maintained (Arnold, 2012; Wade, 2007a, 2007b). Finally, regarding the accounting profession, we note that the lack of (or ineffective) oversight may be a contributing factor to deteriorating audit quality and plunging audit fees, especially in periods of economic stagnation or crisis. Such conditions may eventually incubate major legitimation crises for the profession.

Building a robust system of accounting oversight in a diverse world economy is certainly a perplexing issue. Some of the difficulties inherent in such a project stem from the structural characteristics of delegative democracies and the (in)ability of individual states to effectively introduce externally-induced reforms. Reversing or slowing down the pace of global financial integration, to allow individual countries the time needed to build effective domestic institutions, 
does not seem to be a realistic approach at the current historical juncture (Arnold, 2012). Furthermore, a regression to technocratic self-regulation, which entails higher risk regulatory capture (Hancher \& Moran, 1989), has been abandoned at this point in time. Given these complex issues, and the fact that expertise is currently controlled by Anglo-American audit firms (Botzem, 2012), other approaches for improving accounting oversight on a global scale warrant consideration.

One such approach would be to establish local OBs as public authorities, legally enjoying political, economic, and administrative independence from the government. Such independent bodies, which are recognized as important features of contemporary policy making and reflect an increasing awareness of the role of institutions, aim to increase efficiency and policy credibility (Majone, 1994, 1996). This does not mean that such bodies will, by default, solve the problems in question for delegative democracies. Evidence shows that clientelistic states have a long history of infiltrating new institutions (O'Donnell, 1994). However, such bodies, if established under a nexus of effective provisions for staffing and accountability to parliament regarding their operations, would likely have the potential to spur progress in the successful operation of oversight at the local level.

Another option would be to enhance international coordination of the dispersed national OBs through emerging transnational structures, such as IFIAR (at the global level) and EGAOB (at the regional level), both of which are currently limited to an advisory and coordinating role. Currently, their operation, as our analysis shows, has not mitigated the problems of the Greek OB, despite the groundwork they have laid so far to address the structural problem in the international oversight system. Strengthening international coordination might even lead to some form of effective international (global or regional) OB (Arnold, 2012). This approach might be easier to implement in the case of politico-economic blocks, such as the EU, though it would require considerable coordination and significant hurdles would have to be overcome.

Further research is undoubtedly necessary to establish the generalizability of our findings and their relevance to other locales. Academic inquiry could shed light on the individual histories of accounting OBs in various national contexts, with particular emphasis on their actual performance and impact on the quality of financial reporting and auditing (Arnold, 2012; Malsch \& Gendron, 
2011). In addition to the delegative versus representative construct, other dimensions (e.g. code law vs. common law legal systems) and, more generally, historically-rooted modes of regulation (Puxty et al., 1987), warrant examination for their relationship to the efficacy of emerging oversight institutions. Another issue requiring academic attention is the position of the global profession and key international audit firms regarding regulatory reforms in the EU and US, and the ensuing spread of national OBs across the globe. Of particular interest is the provision, under Section 106 of the Sarbanes-Oxley Act, that PCAOB conduct reviews of the foreign auditors of companies listed in the US; and the potential for avoiding such reviews if a local OB had already conducted audit quality inspections. 


\section{Appendix. The time line of events in the establishment of ELTE}

\begin{tabular}{|c|c|}
\hline July 2002 & $\begin{array}{l}\text { The Ministry of Economy (PASOK) publishes a draft bill providing for the } \\
\text { establishment of ELTE. A consultation period begins immediately and ends in March } \\
\text { 2003. }\end{array}$ \\
\hline March 2003 & $\begin{array}{l}\text { The bill for the establishment of ELTE is introduced in Parliament, having received } \\
\text { only minor amendments during the consultation period. }\end{array}$ \\
\hline April 2003 & $\begin{array}{l}\text { The bill is initially debated in the Standing Committee of Economic Affairs in } \\
\text { Parliament. The OEE secures a position on ELTE's Executive Committee and SOEL } \\
\text { secures a position on ELTE's Administrative Council. }\end{array}$ \\
\hline May 2003 & $\begin{array}{l}\text { The bill is debated in the plenary session of Parliament and voted to become Law } \\
3148 / 2003 \text {. }\end{array}$ \\
\hline August 2003 & $\begin{array}{l}\text { The government fills: } \\
\text { - The posts of ELTE's Executive Committee: the chairman (a partner in a Big-Four } \\
\text { firm), the vice-chairman - SLOT (an independent business accountant), and the } \\
\text { vice-chairman - SPE (an OEE unionist affiliated with PASOK). } \\
\text { - The remaining four posts in ELTE's Administrative Council (representing two } \\
\text { regulatory bodies, the auditing profession, and one business association). }\end{array}$ \\
\hline August 2003 & $\begin{array}{l}\text { One administrative member of staff is appointed (a receptionist-secretary to ELTE's } \\
\text { chairman). }\end{array}$ \\
\hline March 2004 & PASOK loses the elections, and New Democracy takes over. \\
\hline December 2004 & $\begin{array}{l}\text { Law 3301/2004 is passed, bringing ELTE under closer government control and } \\
\text { eliminating the representation of the profession in ELTE's organs of administration. }\end{array}$ \\
\hline February 2005 & $\begin{array}{l}\text { The government: } \\
\text { - Replaces the two vice-chairmen of ELTE and appoints two party affiliates, public } \\
\text { servants at the Ministry of Economy. } \\
\text { - Fills the four posts of SLOT (Accounting Standards Committee). }\end{array}$ \\
\hline March 2006 & The government fills the six posts of SPE (Quality Inspections Committee). \\
\hline June 2007 & $\begin{array}{l}\text { Law } 3581 / 2007 \text { (article 19) significantly increases the power of the chairman of ELTE, } \\
\text { while SPE is essentially abolished as a decision-making body. }\end{array}$ \\
\hline December 2007 & $\begin{array}{l}\text { A committee chaired by the chairman of ELTE is established to propose a law for the } \\
\text { transposition of the (new) Eighth EU Directive. }\end{array}$ \\
\hline July 2008 & $\begin{array}{l}\text { Law 3693/2008 transfers to ELTE all regulatory and oversight power that had hitherto } \\
\text { remained with SOEL. }\end{array}$ \\
\hline April 2009 & A new chairman of ELTE is appointed. \\
\hline May 2009 & Appointment of five audit quality inspectors by ELTE on a one-year contract. \\
\hline April 2010 & The results of the first round of inspections are publicly reported. \\
\hline May 2010 & The audit quality inspectors' contracts expire; the posts remain vacant. \\
\hline May 2010 & $\begin{array}{l}\text { Two audit quality inspectors are appointed by SOEL and seconded to ELTE to deal } \\
\text { with urgent investigations ordered by the Courts of Justice. }\end{array}$ \\
\hline January 2013 & $\begin{array}{l}\text { The number of audit quality inspectors appointed by SOEL and seconded to ELTE } \\
\text { increases to six; as of yet, no audit quality inspections have been completed. }\end{array}$ \\
\hline
\end{tabular}




\section{References}

Academic (trans. 2006). Report to the secretary general of the Ministry of Economy regarding the state of affairs in ELTE. Dated 2 October, Athens.

Academic (trans. 2007). Report to the Minister of Economy about ELTE's situation. Ministry of Economy, Register number 427. Dated 24 January, Athens.

Academic (trans. 2008). Letter to the Minister of Economy about the situation of ELTE's. Ministry of Economy. Register number 192. Dated 22 January, Athens.

Acemoglu, D., \& Robinson, R. (2012). Why nations fail: The origins of power, prosperity, and poverty. New York: Crown Publishers, Random House.

Anantharaman, D. (2012). Comparing self-regulation and statutory regulation: Evidence from the accounting profession. Accounting, Organizations and Society, 37, 55-77.

Arnold, P. (2009a). Global financial crisis: The challenge to accounting research. Accounting, Organizations and Society, 34, 803-809.

Arnold, P. (2009b). Institutional perspectives on the internationalization of Accounting. In Ch. Chapman, D. Cooper, \& P. Miller (Eds.), Accounting, organizations and institutions: Essays in honour of Anthony Hopwood (pp. 48-64). Oxford: Oxford University Press.

Arnold, P. (2012). The political economy of financial harmonization: The East Asian financial crisis and the rise of international accounting standards. Accounting, Organizations and Society, 37, 361381.

ASE (2001). The 125 years of the Athens Stock Exchange. Athens: Stock Exchange Edition.

Babbie, E. (1998). The practice of social research. London: Thomson Publishing.

Balkir, C., Bolukbasi, T., \& Ertugal, E. (2013). Europeanisation in the 'Southern Periphery': Comparative research findings on the EU's impact on domestic political economies. South European Society and Politics, 18(2), 259-280.

Botzem, S. (2012). The politics of accounting regulation: Organizing transnational standard setting in financial reporting, Cheltenham: Edward Elgar.

Bromwich, M., \& Hopwood, A. (1983). Some issues in accounting standard setting: An introductory essay. In M. Bromwich \& A. Hopwood (Eds.), Accounting standard setting: An international perspective (pp. 5-24). London: Pitman.

Büthe, T., \& Mattli, W. (2011). The new global rulers: The privatization of regulation in the world economy. Princeton, NJ: Princeton University Press.

Caramanis, C. (1999). International accounting firms versus indigenous auditors: intra-professional conflict in the Greek auditing profession, 1990-1993. Critical Perspectives on Accounting, 10(2), 153-196.

Caramanis, C. (2002). The interplay between professional groups, the state and supranational agents: Pax Americana in the age of 'globalisation'. Accounting, Organizations and Society, 27, 379-408. 
Caramanis, C. (2005). Rationalisation, charisma and accounting professionalization: perspectives on the intra-professional conflict in Greece, 1993-2001. Accounting, Organizations and Society, 30(3), 195-221.

Caramanis, C., \& Dedoulis, E. (2011). Accounting and auditing practices in Greece. In R. Prouska \& M. Kapsali (Eds.), Business and management practices in Greece (pp. 236-255). Hampshire: Palgrave Macmillan.

Caramanis, C., Dedoulis, E., \& Leventis, S. (2010). The establishment of EU-inspired 'independent' oversight boards: local constrains and the elusive feat of Europeanization in Greece. The $33^{\text {rd }}$ Annual Congress of the European Accounting Association, Istanbul, Turkey.

Caramanis, C., \& Papadakis, V. (trans. 2008). The application of IASs (IFRSs) in Greece: Implications for auditors, business accountants, companies and oversight authorities. Athens: University of Economics and Business.

Chapman, Cooper \& Miller (2009). Linking accounting, organizations and institutions. In Ch. Chapman, D. Cooper, \& P. Miller (Eds.), Accounting, organizations and institutions: Essays in honour of Anthony Hopwood (pp. 48-64). Oxford: Oxford University Press.

Christensen, H., Hail, L., \& Leuz, C. (2013). Mandatory IFRS reporting and changes in enforcement. Journal of Accounting and Economics, 56, 147-177.

Christiansen, T., \& Neuhold, C. (2012a). International handbook on informal governance. Cheltenham: Edward Elgar.

Christiansen, T., \& Neuhold, Ch. (2012b). Introduction. In T. Christiansen \& C. Neuhold (Eds.), International handbook on informal governance (pp. 1-15). Cheltenham: Edward Elgar.

Cooper, D., \& Robson, K. (2006). Accounting, professions and regulation: Locating the sites of professionalization. Accounting, Organizations and Society, 31, 415-444.

Davies, H., \& Green, D. (2008). Global financial regulation. Cambridge: Polity Press.

Denzin, N. K. (1978). The research act: A theoretical introduction to sociological methods. New York: McGraw-Hill.

Dyson, K., \& Goetz, K. (2003). Living with Europe: Power, constraint and contestation. In K. Dyson \& K. Goetz (Eds.), Lining with Europe: Germany, Europe and the politics of constraint. Oxford: Published for the British Academy by Oxford University Press.

Eatwell, J., \& Taylor, L. (2000). Global finance at risk: The case for international regulation. Cambridge, UK: Polity Press.

ELTE (trans. 2009). Advertisement for the appointment of qualified staff of various categories. Decision of Administrative Council, 13 August, Athens.

ELTE (2010). Findings of the first round of audit quality inspections and priorities for 2010. http://www.elte.org.gr (accessed 16 April 2010).

European Commission (1998). Communication from the Commission on the statutory audit in the European Union: The way forward. Official Journal of the European Union, 8.5.1998, p. 12-16 pp. 91-97. 
European Commission (2001a). Commission recommendation of 15 November 2000 on quality assurance for the statutory audit in the European Union: Minimum requirements. Official Journal of the European Union L 091, 31/03/2001, pp. 91-97.

European Commission (2001b). European governance: A white paper. Official Journal of the European Union, C 287 of 12.10.2001.

European Commission (2006). Directive 2006/43/EC of the European Parliament and of the Council of 17 May 2006 on statutory audits of annual accounts and consolidated accounts, amending Council Directives 78/660/EEC and 83/349/EEC and repealing Council Directive 84/253/EEC. Official Journal of the European Union, L 157, 9.6.2006, p. 87-107.

European Commission (2010). Audit policy: Lessons from the crisis. Green paper COM(2010), 561, Brussels.

Express (2007). Zafiropoulos appointed non-executive director. Date: 27 July 2007, p. 13.

Falkner, G., \& Treib, O. (2008). Three worlds of compliance or four? The EU-15 compared to new member states. Journal of Common Market Studies, 46(2), 293-313.

Falkner, G., Treib, O., Hartlapp, M., \& Leiber, S. (2005). Complying with Europe: EU harmonisation and soft law in the member states. Cambridge: Cambridge University Press.

Featherstone, K., \& Papadimitriou, D. (2008). The limits of Europeanization: Reform capacity and policy conflict in Greece, Hampshire: Palgrave Macmillan.

Government Gazette (trans. 2003). Law 3148: The establishment of the accounting standardization and audits committee and other provisions. National Printing Office, A/136/05-06-2003, Athens.

Government Gazette (trans. 2004). Law 3301: Agreements for the provision of financial security, the application of International Accounting Standards and other provisions. National Printing Office, A263/23-12-2004, Athens.

Government Gazette (trans. 2005). Ministerial Decision 5983/115, Re: Appointment of members of SLOT, Ministry of Economy. National Printing Office, B/323/11-03-2005, Athens.

Government Gazette (trans. 2009). Decision 17779/524 Re: Changes in the composition of ELTE's Executive Committee. 154/10-04-2009, National Printing Office, Athens.

Greek Parliament (trans. 2003a). The official proceedings of the discussion of Law 3148/2003. Standing Committee of Economic Affairs, 15 April, Athens.

Greek Parliament (trans. 2003b). The official proceedings of the discussion of Law 3148/2003.Standing Committee of Economic Affairs, 17 April 2003, Athens.

Greek Parliament (trans. 2003c). The official proceedings of the discussion on Law 3148/2003. Parliamentary Debates, 8 May, Athens.

Hancher, L., \& Moran M. (1989). Organising regulatory space. In L. Hancher \& M. Moran (Eds.), Capitalism, culture and economic regulation (pp. 271-299). Oxford: Oxford University Press.

Hopkin, J. (2006). Clientelism and party politics. In W. Crotty, \& R. Katz (Eds.), Handbook of party politics (pp. 406-412). London: Sage. 
Hopwood, A.G. (2000). Understanding financial accounting practice. Accounting, Organizations and Society, 25(8), 763-766.

Hopwood, A. G. (2009). The economic crisis and accounting: Implications for the research community. Accounting, Organizations and Society, 34, 797-802.

Humphrey, C., Loft A., \& Woods, M. (2009). The global audit profession and the international financial architecture: Understanding regulatory relationships at a time of financial crisis.

Accounting, Organizations and Society, 34, 810-825.

Hussey, J., \& Hussey, R. (1997). Business research: The practice of social research. London: Macmillan Press.

IFIAR (2014). IFIAR Core Principles. The International Forum of Independent Audit Regulators. https://www.ifiar.org/Reports.aspx (accessed 20 April 2014).

International Monetary Fund (2013). Global financial stability report: Old risks, new challenges. World economic and financial surveys. Washington, DC: IMF.

Jick, T.D. (1979). Mixing qualitative and quantitative methods: Triangulation in action. Administrative Science Quarterly, 24, 601-611.

Katseli, L. (trans. 2009). The operation of ELTE and the state of financial reporting and auditing. National Parliament, Parliamentary Question No. 16374/18-03-09, Athens.

Kaufmann, D., Kraay, A., \& Mastruzzi, M. (2013). The Worldwide Governance Indicators, World Bank. http://info.worldbank.org/governance/wgi/index.aspx\#home.

Kerdos (trans. 2002). Strict audit quality inspections aim at transparent management of companies. July 10, pp. 37-39.

Kerdos (trans. 2008). The deficiencies of the oversight authorities cast doubt on the benefits from the introduction of IFRSs. October 19, pp. 14-15.

Kopecky, P., \& Scherlis, G. (2008). Party Patronage in Contemporary Europe. European Review, $16(3), 355-371$.

Kourkouta, M. (trans. 2008, 17 October). The application of IFRSs in Greece. Epsilon 7, 4-7.

Kousoulos, P., \& Vlachoutsakos, P. (2012). Public prosecutor scrutinizes the auditors. www.zougla.gr/greece/article/isageliko-kseskonisma-gia-tous-elegtes (accessed 16 February 2013).

Lennox, C., \& Pittman, J. (2010). Auditing the auditors: Evidence on the recent reforms to the external monitoring of audit firms. Journal of Accounting and Economics, 49, 84-103.

Leuz C. Nanda, D., \& Wysocki, P. (2003). Earnings management and investor protection: An international comparison. Journal of Financial Economics, 69, 505-527.

Lyrintzis, C. (1984). Political Parties in Post-junta Greece: A Case of "Bureaucratic clientelism?", in Geoffrey Pridham (ed.), The New Mediterranean Democracies. London: Frank Cass.

Lyrintzis, C. (2005). The changing party system: Stable democracy, contested 'modernisation'. West European Politics, 28(2), 242-259. 
Malsch, B., \& Gendron, Y. (2011). Reining in auditors: On the dynamics of power surrounding an "innovation" in the regulatory space. Accounting, Organizations and Society, 36, 456-476.

Ministry of Economy (trans. 2002). Letter requesting comments on draft bill, re: “The establishment of the Accounting Standardization and Audit Committee”. Ministry of Economy. Dated 18 July, Athens.

Ministry of Economy (trans. 2006). Ministerial Decision 14581/382: Appointment of Members of the Quality Inspections Committee (SPE). Ministry of Economy. Dated 30 March, Athens.

Mouzelis, N. (1995). Greece in the twenty-first century: institutions and political culture. In D. Constas \& Th. Stavrou (Eds.), Greece prepares for the twenty-first century (pp. 17-34). Washington: Woodrow Wilson Center Press.

Naftemporiki (trans. 2003). The Administrative Council of ELTE is appointed. August 23, p. 3.

Naftemporiki (trans. 2005). Changes in ELTE's Administrative Council. February 7, pp. 4.

Naftemporiki (trans. 2008,). Three years with IFRSs. October 17, pp. 18-19.

Nikolopoulos, N. (trans. 2014). Conflict of interest for ELTE's leadership. National Parliament, Parliamentary Question of 16 January 2004. http://tro-ma-ktiko.blogspot.gr/2014/05/blogpost_7651.html (accessed on 15 March 2014).

O’Donnell, G. (1994). Delegative democracy. Journal of Democracy, 5(1), 55-69.

OECD (2009). Economic Outlook, no. 86, November, pp. 178-180 (available at http://www.oecd.org/document/2/0,3746,en_2649_34109_2082818_1_1_1_1,00.html Accessed 28.05.2012).

OECD (2010). Economic Outlook, no. 86, November, pp. 178-180, (available at http://www.oecd.org/document/2/0,3746,en_2649_34109_2082818_1_1_1_1,00.html Accessed 28.05.2012).

OECD (2011a). Economic Outlook, no. 86, November, pp. 178-180, (available at http://www.oecd.org/document/2/0,3746,en_2649_34109_2082818_1_1_1_1,00.html Accessed 28.05.2012).

OECD (2011b). Greece: Review of the Central Administration, OECD Public Governance Reviews, OECD Publishing (available at http://dx.doi.org/10.1787/9789264102880-en).

OECD (2012). Economic Outlook, no. 86, November, pp. 178-180, (available at http://www.oecd.org/document/2/0,3746,en_2649_34109_2082818_1_1_1_1,00.html Accessed 28.05.2012).

Osma, B.G., \& Pope, P. (2011). Strategic balance sheet adjustments under first-time IFRS adoption and the consequences for earnings quality. Working paper, International Centre for Research in Accounting, Lancaster University.

Pagoulatos, G. (2003). Greece's new political economy: state, finance and growth from post war to EMU. London: Palgrave Macmillan.

Papadimitriou, Ch. (2001). The Greek economy. Kathimerini, 21 June. http://www.kathimerini.gr/94158/article/oikonomia/ellhnikh-oikonomia/makroskopika. 
Papakostas, A. (2001). Why is there no clientelism in Scandinavia? A comparison of the Swedish and Greek sequences of development. In S. Piattoni (Ed.), Clientelism, interests and democratic representation (pp. 31-53). Cambridge: Cambridge University Press.

Piattoni, S., (2001). Clientelism in historical and comparative perspective. In S. Piattoni (Ed.), Clientelism, interests, and democratic representation (pp. 1-30). Cambridge: Cambridge University Press.

Power, M. (2009). Financial accounting without a state. In Ch. Chapman, D. Cooper, \& P. Miller (Eds.), Accounting, organizations and institutions: Essays in honour of Anthony Hopwood (pp. 324340). Oxford: Oxford University Press.

Puxty, A.G., Willmott, H.C., Cooper, D.J., \& nd Lowe, T. (1987). Modes of regulation in advanced capitalism: locating accountancy in four countries. Accounting, Organizations and Society, 12(3), 273-291.

Radaelli, C. M. (2003). The Europeanisation of public policy. In K. Featherstone \& C. M. Radaelli (Eds.), The Politics of Europeanisation (pp. 27-56). Oxford: Oxford University Press.

Refenes, A. (trans. 2011). In "difficult years" incidents of falsification "creative" reporting increase. Accountancy Greece, 2, 26-31.

Refenes, A. (trans. 2013). Interview with Accountancy Greece, 19 July, 213. http://www.accountancygreece.gr/ $\alpha \pi 0 \sigma \tau \circ \lambda \sigma \sigma-\rho \varepsilon \varphi \varepsilon v \varepsilon \sigma /$ (accessed on 10 September 2013).

Retired Judge (trans. 2006a). Letter to ELTE's Executive Committee Highlighting Certain Legal Aspects in Relation to the Selection of Quality Inspections Auditors. Dated 3 November, Athens.

Retired Judge (trans. 2006b). Letter to ELTE's Executive Committee Suggesting that Quality Inspections should not be Delayed. Dated 20 November, Athens.

Roniger, L. (2004). Political clientelism, democracy and market economy. Comparative Politics, 36(3), 353-375.

Schmitter, P. (1974). Still the century of corporatism? Review of Politics, 36, 85-131.

Second-tier firm partner (trans. 2002). Letter to the Supervisor Council of SOEL regarding SOEL's proposals to the Ministry of Economy about the creation of ELTE. Dated 24 September, Athens.

Simon, H. (1962). The architecture of complexity. Proceeding of the American Philosophical Society, Vol. 106, no. 6. December, pp.467-482.

SLOT (trans. 2005). Internal Organization Charter. April, ELTE, Athens.

Staikouras, P. (2001). Lessons from the mishaps. Kauthimerini, 2 June 2001, http://www.kathimerini.gr/93152/article/oikonomia/ellhnikh-oikonomia/pa8hmata-kai-ma8hmata-hmonon-pa8hmata.

Streeck, W., \& Schmitter, Ph. (1985). Community, market, state and associations? The prospective contribution of interest governance to social order. In W. Streeck \& Ph. Schmitter (Eds.), Private interest government: Beyond market and state (pp. 1-29). London: Sage Publications.

Tatoulis, P. (trans. 2009). The operation of ELTE and the state of financial reporting and Auditing.National Parliament, Parliamentary Question 16057/18-03-09, Athens. 
To Vima (trans. 2009). The application of IFRSs in Greece. January 6, 8.

Trichet, J.C. (trans. 2014). Interview with daily Greek Kathimerini, 19 January, http://portal.kathimerini.gr/4dcgi/_w_articles_kathfiles_1_19/01/2014_536396, accessed on 20 January 2014.

US Congress (2002). Public Law 107-204 (the Sarbanes-Oxley Act).July 30. http://www.gpo.gov/fdsys/pkg/PLAW-107publ204/content-detail.html Accessed 1.6.2012.

US Congress (2010). The Dodd-Frank Wall Street Reform and Consumer Protection Act. http://www.sec.gov/about/laws/wallstreetreform-cpa.pdf Accessed 1.6.2012.

Wade, R. H. (2007a). A new global financial architecture? New Left Review, 46, 113-129.

Wade, R. H. (2007b). The aftermath of the Asian financial crisis: From "liberalize the market" to "standardize the market" and create a "level playing field". In B. Muchhala (Ed.), Ten years after: Revisiting the Asian financial crisis (pp. 73-94). Washington, DC: Woodrow Wilson International Center for Scholars.

World Economic Forum (2004). The Lisbon review 2004: An assessment of policy and reforms in Europe. Geneva: World Economic Forum.

World Economic Forum (2006). The Lisbon review 2006: Measuring Europe's process in reform. Geneva: World Economic Forum.

Yin, R. (2002). Case study research: Design and methods. Third edition, London: Sage.

Zeff, S. (2003). How the US accounting profession got where it is today. Accounting Horizons, 17, 189-205. 